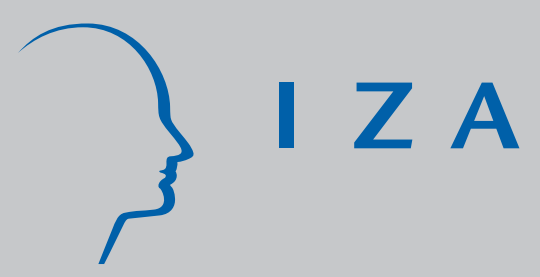

IZA DP No. 2261

Immigrant-Native Differences in Welfare Participation:

The Role of Entry and Exit Rates

J örgen Hansen

Magnus Lofstrom

August 2006 


\title{
Immigrant-Native Differences in Welfare Participation: The Role of Entry and Exit Rates
}

\author{
Jörgen Hansen \\ Concordia University, \\ CEPR, CIRANO, CIREQ and IZA Bonn
}

Magnus Lofstrom

University of Texas at Dallas

and IZA Bonn

Discussion Paper No. 2261

August 2006

\author{
IZA \\ P.O. Box 7240 \\ 53072 Bonn \\ Germany \\ Phone: +49-228-3894-0 \\ Fax: +49-228-3894-180 \\ Email: iza@iza.org
}

\begin{abstract}
Any opinions expressed here are those of the author(s) and not those of the institute. Research disseminated by IZA may include views on policy, but the institute itself takes no institutional policy positions.
\end{abstract}

The Institute for the Study of Labor (IZA) in Bonn is a local and virtual international research center and a place of communication between science, politics and business. IZA is an independent nonprofit company supported by Deutsche Post World Net. The center is associated with the University of Bonn and offers a stimulating research environment through its research networks, research support, and visitors and doctoral programs. IZA engages in (i) original and internationally competitive research in all fields of labor economics, (ii) development of policy concepts, and (iii) dissemination of research results and concepts to the interested public.

IZA Discussion Papers often represent preliminary work and are circulated to encourage discussion. Citation of such a paper should account for its provisional character. A revised version may be available directly from the author. 
IZA Discussion Paper No. 2261

August 2006

\section{ABSTRACT \\ Immigrant-Native Differences in Welfare Participation: The Role of Entry and Exit Rates}

This paper analyzes differences in welfare transitions between natives and immigrants in Sweden using a large representative panel data set, LINDA, for the years 1991 to 2001 . The data contains administrative information on welfare use, country of birth, and time of arrival in Sweden among other things, and provides an excellent opportunity to examine immigrantnative differences in welfare use. The empirical results suggest that the main reason for the large immigrant-native welfare gap observed in the data is differences in welfare entry rates. Thus, policies aimed to reduce these transitions may be particularly successful in reducing welfare use in general and the immigrant-native welfare gap in particular.

JEL Classification: $\quad 130,138, \mathrm{~J} 15, \mathrm{~J} 18, \mathrm{~J} 61$

Keywords: $\quad$ welfare, immigration, labor market behavior, transition, state dependence

Corresponding author:

Magnus Lofstrom

University of Texas at Dallas

School of Social Sciences

P.O. Box 830688

GR 31

Richardson, TX 75083-0688

USA

E-mail: lofstrom@utdallas.edu

\footnotetext{
* We would like to thank Ken Chay for providing programming code for estimation of the fixed effects logit specification utilized.
} 


\section{Introduction}

The increase in immigration experienced by many Western countries in the last decade has led to raised concerns regarding immigrant over-utilization in welfare programs. In fact, this concern has incited some countries to restrict access to some government transfer programs for immigrants. In the U.S. for example, The Personal Responsibility and Work Opportunity Reconciliation Act (PRWORA) of 1996, restricts non-citizens who arrived after 1996 the right to receive most types of public assistance. In Germany, immigrants without permanent residency may lose the right to stay in the country or may be denied residency extensions if they depend on social assistance. Although the country studied in this paper, Sweden, does not treat immigrants differently from natives with respect to social assistance, immigration is central to the welfare debate. By the mid-1990's immigrants in Sweden accounted for nearly half of the country's expenditure on social assistance. ${ }^{1}$ This is quite remarkable since immigrants represent approximately an 11 percent minority of the population (roughly the same foreign born population proportion as in the US, the UK, Austria, Belgium, France and the Netherlands). In addition, given that real expenditures on the social assistance program in Sweden increased by 170 percent between 1983 and 1996 and that the share of immigrants in the population during the same period increased from 7.6 percent to 10.8 percent, it is clear that understanding immigrants' welfare utilization is essential in explaining the expenditure trend.

Several studies have examined differences in welfare participation between immigrants and natives (see for instance Baker and Benjamin, 1995; Borjas and Hilton, 1996; Hansen and Lofstrom, 2003 and Riphahn, 1998 for Canada, the U.S., Sweden and Germany respectively). However, to our knowledge, no study has analyzed immigrant welfare entry and exits, mainly due to a lack of representative panel data with sufficiently large number of foreign born individuals. Understanding the dynamic processes underlying the observed utilization of government transfer programs is essential, as pointed out by Plant (1984). Of interest is also whether there are differences in the

\footnotetext{
${ }^{1}$ The increase in welfare expenditures can at least partially be explained by the increase in refugee immigrants from former Yugoslavia who arrived during this period.
} 
transitions between foreign and native born. This is of particular importance since immigrants are commonly found to be more likely to participate in welfare programs than natives in, for example, Sweden, Germany and the U.S. (Hansen and Lofstrom, 2003; Riphahn, 1998 and Borjas and Hilton, 1996). An important question is whether the higher participation rates are due to higher entry rates among immigrants or lower exit rates, or a combination of the two. If, for example, immigrant and native welfare entry rates are similar, but immigrants display lower welfare exit rates, this would suggest that welfare is more of a temporary income support for native households than among immigrant households, who once they have started to receive assistance, may have difficulties leaving welfare.

In this paper we confine the analysis to transitions into and out of welfare and/or unemployment. Given that welfare may act as a form of unemployment insurance, particularly for new immigrants who are not yet eligible for the existing unemployment compensation programs, we consider alternative definitions of welfare participation to address this issue. Our goal is to answer the following questions: Are the greater welfare participation rates among immigrants due to differences in entry and/or exit rates and what are the specific roles of differences in welfare dynamics on the immigrant-native welfare gap? We also address the question of what factors affect welfare transition probabilities.

To answer these questions we estimate dynamic logit models, controlling for both endogenous initial condition and unobserved heterogeneity, taking advantage of a large nationally representative longitudinal data set, Longitudinal Individual Data (LINDA). The data utilized contains information on more than 300,000 individuals annually for the period 1991 to 2001. The data is collected from administrative records which imply essentially no attrition and equally important, accurately reported welfare status.

The data show that immigrants are more likely to stay on welfare, or to receive unemployment insurance, given participation in the previous year and are less likely to exit welfare/unemployment in consecutive years than natives. Our empirical results suggest that the main reason for the immigrant-native welfare gap is differences in welfare entry rates. When using natives' estimated entry rates in predicting welfare participation for immigrants, we found that the welfare gap diminished substantially. 
While using natives' estimated exit rates also reduced the gap, the reduction was substantially smaller. Our results also indicate that immigrant-native differences in observable characteristics are not the main contributors to the immigrant-native welfare gap.

Although some aspects of the immigrant welfare experiences are likely to be unique to Sweden, the many similarities in the immigrant and asylum seeker inflow, including how refugee immigrants are introduced to the new countries' public assistance systems and the difficulties faced in the labor market, suggests that our results are informative to the immigration debate in other countries.

The paper is organized in the following way. In section 2 we give background information about immigration, the social assistance program and unemployment insurance in Sweden. Section 3 describes the data and variables while Section 4 depicts trends and differences, between immigrants and natives, in government transfer program participation and transitions. In Section 5 we present the model and empirical specification. We discuss the results in Section 6 and conclude in Section 7.

\section{Immigration and Welfare Programs in Sweden}

One important reason for the increase in welfare participation during the first half of the 1990's, and the consequent growth in expenditures, was the widespread downturn in the economy and the subsequent rise in unemployment during this period. Figure 1 shows separately the unemployment rate for Swedish and foreign citizens between 1991 and 2001. ${ }^{2}$ The official unemployment rate, among Swedish citizens, grew from 1.7 percent in 1990 to around 8 percent in 1996 and 1997. For foreign citizens, the labor market deteriorated even more. In 1990, approximately 4 percent were unemployed. This had increased to 25 percent by 1997. Even though the unemployment rates for foreign citizens decreased more than those for Swedish citizens in the subsequent period, a large gap remains in 2001. Additionally, the increase in welfare expenditures in Sweden in the

\footnotetext{
${ }^{2}$ We lack information on separate unemployment rates for natives and immigrants for this period. It should be noted that the group of Swedish citizens include naturalized foreign-born individuals.
} 
1990's can partly be explained by the large inflows of immigrants who arrived during this period, who were not yet eligible for unemployment insurance, and therefore had to rely on social assistance for their subsistence.

\section{Immigration into Sweden}

The inflow of immigrants to Sweden has undergone a number of changes during the last six decades. Figure 2 shows annual immigration to Sweden from 1940 to 2001, both in terms of the level of the immigrant inflow and inflow expressed as the proportion of the total population in the corresponding year. Overall, annual immigration has amounted to about 0.4 percent of the population, but notably higher during the 1990's. Naturally, the large inflow of immigrants has also changed the composition of the population in Sweden.

The reasons people immigrate to Sweden have changed substantially since WorldWar II. In principle, we can distinguish between three categories of immigrants, based on the reasons for immigration: economic migrants (e.g. due to the recruitment of labor), tied movers (i.e. family ties) and refugees. In the late 1940's, a large fraction of the immigrants arrived in Sweden as refugees, mainly from the Nordic countries. However, in the period from 1950 to 1970, most of the immigrants were recruited by the Swedish industry or migrated because of family ties. The recruitment of foreign workers during the 1950's and 1960's was also prevalent in other European countries, such as Austria, Germany and the Netherlands (Bauer et al, 2000). From 1970 and onwards, the proportion of immigrants arriving as refugees has increased significantly, from less than 10 percent of the immigrant inflow in 1970 to about 70 percent in the early 1990's. In 1994, this proportion dropped from 70 percent to about 50 percent, mostly due to the improved conditions in the Balkan countries. Since the 1980's, roughly 1/3 of refugee immigrants migrated from former Yugoslavia and approximately 1/4 from Iran and Iraq. Overall, about one half of immigrants in Sweden today come from Europe, of these, 40 percent are Nordic citizens.

\section{Social Assistance in Sweden}


The Swedish welfare system is well known internationally for the high degree of income security that it provides for its citizens. Recently, this generous system has been the target of a number of reforms, mainly due to the recession that hit Sweden, and many other countries, in the early 1990's.

As an ultimate safety net, people in Sweden are covered by social assistance (SA). As with unemployment insurance, the eligibility rules and benefit levels are the same for immigrants and natives. In order to be eligible for SA, all other welfare programs, such as unemployment compensation, housing allowance (bostadsbidrag), child allowance (barnbidrag), maintenance allowance (underhållsbidrag) and various pensions, must be exhausted first. The benefit levels vary both across family types and regions, but are intended to cover expenses essential for a "decent" standard of living. To be eligible for SA benefits, a family must have income and assets below certain specified benefits levels, known as norms. The norms were, until 1998, determined in each of the 288 municipalities in Sweden. However, as of the $1^{\text {st }}$ of January 1998, the regional variations in the norms were replaced by a national norm in order to reduce the inequality aspect of having differentiated benefit levels across municipalities. ${ }^{3}$ The norms serve as guidelines for the social worker who decides the actual size of the benefits. SA benefits are paid according to a schedule that sets a guarantee amount for a family of a given size. These benefits are reduced at a 100 percent reduction rate as the family's income rises.

\section{Unemployment Insurance in Sweden}

The Swedish unemployment insurance system consists of two parts: unemployment benefits (Arbetslöshetskassa, UB) and unemployment assistance (Kontant arbetsmarknadsstöd, UA). In 1990, the coverage was slightly less than 80 percent of the labor force, with roughly 70 percent covered by UB and 10 percent by UA. To be entitled to compensation from UB, an unemployed worker must have paid membership fees to the

\footnotetext{
${ }^{3}$ According to the national norm in 1998, a single person would receive 2,884 SEK per month in SA while a couple with two children would receive about 7,500 SEK per month (depending on the age of the children). These amounts are intended to cover expenses for so called necessary consumption, such as food, basic clothing, leisure, health, newspapers, telephone and fees for TV, and partially for housing. The SA system also grants the right to so called reasonable housing, which is not included in the norm amount. The additional assistance for housing is known as "bostadsbidrag". In 1998, the exchange rate was roughly 8 SEK per U.S. Dollar, about the same as the current, 2006, exchange rate.
} 
UB fund for the last 12 months and must have been working for at least 75 days preceding the current unemployment spell. These conditions imply that many of the new entrants in the labor market, such as young workers and immigrants, are not entitled to compensation from UB. There is a time limit on UB and entitled workers can receive benefits for a maximum of 300 working days. Compared to non-Scandinavian countries, the benefit levels are quite generous with replacement rates varying between 75 and 90 percent during the 1990's. ${ }^{4}$

Workers who are not eligible for receiving UB may be entitled to compensation from UA. There exists a similar work requirement for receiving UA as for receiving UB, but there is no "membership" requirement. However, UA is substantially less generous than UB, both in terms of benefit duration and compensation levels. ${ }^{5}$

\section{Immigration and Welfare in Other Developed Countries in the 1990s}

Sweden's immigrant experience in the 1990s is not unique, particularly regarding refugees and welfare. The inflow of new refugee immigrants in Europe has put an increased pressure on immigrant public assistance expenditure and hence increasing efforts have been taken to integrate immigrants effectively into the respective labor markets (SOPEMI, 2000). Like Sweden, Austria, France, Germany, the Netherlands and the United Kingdom, among others, received large numbers of asylum seekers during the 1990's. The policy of introducing refugees to public assistance upon arrival in the new host country is not surprising given the limited available opportunities for self-support and is also utilized in, for example, Germany (Riphanh, 1998) and the Netherlands (van Ours and Veenman, 1999). U.S. policy also recognizes the difficult situation faced by newly arrived refugee immigrants and consequently, non-naturalized refugees in the U.S. are exempt from the restrictions placed on immigrant access to welfare introduced by PRWORA. Lastly, the relationship between immigrant and native unemployment is not unique to Sweden. Like Sweden, immigrants in Austria, Belgium, France and the

\footnotetext{
${ }^{4}$ Until 1993, the UB replacement rate was 90 percent of earnings up to a maximum level determined by the government. In July 1993, the replacement rate was reduced to 80 percent and in January 1996, it was further reduced to 75 percent. The replacement rate was raised back to 80 percent in September of 1997. It should be noted that the actual unemployment compensation received through UB is frequently less than the replacement rate due to a relatively low maximum benefit amount.
} 
Netherlands, also experience unemployment rates that are at least twice as high as the ones experienced by the native born population (SOPEMI, 2003).

\section{Data}

\section{Description of the Data and Sampling Procedures}

The data used in this paper is obtained from a recently created Swedish longitudinal data set, Longitudinal Individual Data (LINDA). LINDA is a register-based data set and it consists of a large panel of individuals, and their household members, which are representative for the population from 1960 to 2001. LINDA is a joint endeavor between the Department of Economics at Uppsala University, The National Social Insurance Board (RFV), Statistics Sweden, and the Ministries of Finance and Labor. The main administrator of the data set is Statistics Sweden. LINDA contains a 3 percent representative random sample of the Swedish population, corresponding to approximately 300,000 individuals for the period studied here. The sampled population consists of all individuals, including children and elderly persons, who live in Sweden in the given year. The sampling procedure used in constructing the panel data set ensures that each cross-section is representative for the population in each year. For a more detailed description of the data used here, including the sampling structure, see Edin and Fredriksson (2000).

The sample used in this study consists of information from LINDA for the years 1991-2001 and consists of men and women between the ages of 18 and 65. We exclude students and retired individuals. Furthermore, we restrict our sample to a balanced panel over the entire period, yielding a sample size of 92,223 individuals. As a sensitivity check, we estimate our models using an unbalanced panel. ${ }^{6}$ We define a person to be an immigrant if he/she was born abroad, and a refugee immigrant if he/she was born in a refugee country, as defined by the Swedish Immigration Board, or in a sub-Saharan

\footnotetext{
${ }^{5}$ Under the UA program, an unemployed worker receives approximately $200 \mathrm{SEK} /$ day, corresponding to roughly 30 percent of average earnings, and the maximum benefit period is 150 working days.

6 This is may be of particular importance since the balanced panel does not include immigrants who arrived after 1991.
} 
country. ${ }^{7}$ If the person is an immigrant or a refugee, we have information about the year of arrival in Sweden. ${ }^{8}$ Table 1 shows summary statistics for the three groups, natives, immigrants from non-refugee and immigrants from refugee countries separately for men and women. In the subsequent analysis, we include immigrants who have been in Sweden for at least two years in a given time period. The reason for this sample selection is that the great majority of refugee immigrants receive welfare upon arrival to Sweden automatically. The immigration board then assists the refugee immigrants in various activities, including language training, in order to ease them into the labor market. A typical "integration" period lasts for 1-2 years. During this time, the immigrant is particularly limited in their choice of labor market states. Including these immigrants may therefore overstate the state dependence in welfare use among immigrants. To ensure that our results are not driven by this exclusion restriction, we estimated the models reported below including the most recent immigrants. The welfare dependence among refugee immigrants increases somewhat, as expected, but the conclusions regarding welfare dynamics remain largely unchanged. ${ }^{9}$

\section{Variable Definitions}

To answer the questions regarding welfare persistence in Sweden, we estimate dynamic logit models controlling for both unobserved individual heterogeneity and initial conditions. We want to capture dependence on two important government transfer programs that may serve different roles for immigrants and natives; receipt of social

\footnotetext{
${ }^{7}$ The countries defined by the Swedish Immigration Board as refugee countries: Ethiopia, Afghanistan, Bulgaria, Bangladesh, Bosnia, Chile, Sri Lanka, Cuba, Iraq, Iran, India, Yugoslavia, China, Croatia, Lebanon, Moldavia, Peru, Pakistan, Poland, Russia, Soviet Union, Romania Somalia, Syria, Togo, Turkey, Ukraine, Uganda and Vietnam. However our refugee/non-refugee country definition is time variant with respect to arrival year. For example, immigrants from Yugoslavia who arrived prior to 1975 are defined as non-refugee immigrants and immigrants from the former Eastern Bloc countries, including the Soviet Union, who arrived after 1995 are also defined as non-refugee immigrants.

${ }^{8}$ All immigrants included in LINDA, whether defined as refugees or not, have obtained residence permits. This means, for instance, that asylum seekers who have not yet obtained a residence permit are not included in LINDA. Furthermore, the data does not allow us to identify the exact year of arrival for immigrants who arrived in 1968 or earlier.

${ }^{9}$ The possibility of non-random return migration is another reason to define the immigrant sample in this way. Edin et al (2000) find that that return migration among refugees is low, less than 10 percent within 5 years since arrival, and if an immigrant is to leave Sweden, it is most likely to take place within the first few years after arrival. By excluding the most recent immigrants we may decrease the potential effects of return migration on our estimates. We also find it comforting that the results do not change very much between the samples with and without the years since migration restriction.
} 
assistance and unemployment compensation. Since many immigrants, particularly recently arrived immigrants, may not be eligible to receive unemployment benefits, we utilize two alternative state definitions. One is simply for receiving social assistance and the alternative measure is for collecting social assistance and/or unemployment compensation.

Since LINDA lacks information about individuals' time allocation, we need to rely on the income sources to classify individuals into the welfare states. We define individuals as welfare recipients if they received social assistance for at least one month during the year. We classify a person as a welfare/UI recipient if he or she received welfare for at least a month and/or received more than one-half of the so-called "basic amount", SEK 18,100, in unemployment benefits during the year. ${ }^{10}$ Previous research has found greater sensitivity in public assistance participation to local labor market conditions among immigrants than natives in the U.S. (Lofstrom and Bean, 2002). To address this issue, local labor market variables are assigned to each individual in each year based on the individual's municipality of residence. The information is obtained from Statistics Sweden's labor force surveys.

\section{Welfare Entry, Exit and Participation}

Sweden experienced an increase in immigration in the 1990's. During this period the economy was also entrenched in a severe recession, with a trough around 1993-94 which only moderately leveled off by 1996. Throughout the period studied here, immigrants participated to a greater extent in social assistance, as well as our measures for receipt of either unemployment compensation and/or social assistance programs, than natives did, shown in Appendix Table A1. Furthermore, non-refugee immigrants utilized these programs less than refugees. The table also suggests that there is a greater difference between immigrant and native welfare utilization than in the immigrant-native difference in participation in the unemployment insurance programs. For example, the average welfare participation rate for male refugee immigrants during the 1991-2001 
period was roughly six times higher than the average utilization rates for native born males. The average combined Welfare/UI participation rate was “only” around three times as high for refugees, relative to natives. The discrepancy in the relative utilization rates in the programs between immigrants and natives is at least partially due to UI ineligibility for, in particular recent, refugee immigrants. The table also shows that the immigrant-native participation gap is smaller for women than men.

There are substantial differences in the dynamic welfare behavior between immigrants and natives. Table 2 shows transition probability matrices separately for the three groups, as well as by gender. This table reveals several interesting relationships and patterns. We first examine the issue of state dependence, i.e. the probability of staying on welfare in two consecutive years, in the raw data. The data shows that immigrants are more likely to receive welfare in a given year, conditional on having received welfare in the previous year. The probability that native born men will stay on welfare in two consecutive years is 0.62 , while for both non-refugee and refugee immigrants it is higher, 0.66 and 0.72 respectively. This relative relationship holds for our alternative welfare measure which includes participation in either social assistance and/or UI, but the differences are somewhat smaller. Clearly, these results also mean that immigrants are less likely to move out-of welfare than natives. As with the unconditional participation probabilities, the differences across groups are smaller for women. In fact, there appear to be no difference in the probability to stay on welfare in two consecutive years for native born and non-refugee women.

Conditional on not receiving welfare or unemployment compensation in a given year, it also appears that immigrants are more likely to collect either welfare or UI than natives are in the next year. Table 2 shows that about 1 percent of native males move from non-welfare dependence to welfare participation in consecutive years. The equivalent entry transition probability for refugee immigrants is slightly greater than 0.05, while it is close to 0.03 for non-refugee immigrants. If UI is included, the probability of shifting into welfare increases to 0.04 for native males, 0.05 for nonrefugee immigrants and to almost 0.1 for immigrants from refugee countries. As with the

\footnotetext{
10 The seemingly arbitrary value of annual unemployment compensation chosen to indicate unemployment, 18,100 SEK, refers to one-half of the so called "basic amount" or basbelopp in Swedish. The results presented below do not appear to be sensitive to alternative levels of annual unemployment compensation.
} 
above reported probabilities, the differences across nativity groups are smaller for women. ${ }^{11}$

One of the objectives of this paper is to study the determinants of the transitions, or movements, in and out-of public assistance, and if there are any differences in these determinants between immigrants and natives. However, before we analyze the observed disparity in the behavior of immigrants and natives, we want to briefly examine differences in the observable characteristics between individuals who stay in a particular state and the ones who change states. Appendix Tables A3 and A4 show mean characteristics by previous year's state separately for men and women by nativity group. In general, it appears that any movements out of welfare are associated with higher educational attainment, being married and having more children. Also a general relationship for state dependency appears to be age, namely, older individuals seem to be less likely to move out of previous year's state. Immigrants who have been in Sweden a longer time appear to be more likely to move out-of welfare and less likely to move into welfare.

The descriptive statistics indicates that immigrants are more likely to utilize both welfare and unemployment compensation than natives. Immigrants from refugee countries participate in these transfer programs to a greater extent than non-refugee immigrants. This is caused by both lower welfare exit probabilities and higher welfare entry rates. The immigrant-native gap is particularly large for immigrants from refugee countries.

Some of the above discussed differences between immigrants and natives may be due to differences in schooling levels, age, marital status, family composition, geographic location and local labor market conditions, but also to individual characteristics that are unobservable to the econometrician.

\footnotetext{
${ }^{11}$ Given the differences in transition probabilities between immigrants and natives, we would also expect the distribution of the number of welfare and labor market spells to differ across groups. Table A2 shows the distribution of these spells for the balanced panel. Approximately 90 percent of native men did not utilize social assistance at all during the period 1991-2001, while only slightly more than half of refugee immigrants experienced no welfare participation spell. Close to 3 percent of refugee immigrants collected welfare for each of the eleven years. The respective figure for natives is substantially lower, 0.3 percent. Non-refugee immigrant men are utilizing social assistance less frequently than immigrants from refugee countries. These patterns hold up for the measure also including UI, as well as for women, although the differences are again smaller than what they are for men.
} 


\section{Model and Empirical Specification}

To analyze transitions into and out of welfare, we estimate a dynamic logit model designed to control for unobserved heterogeneity and endogenous initial conditions. We further assume that the dynamic structure of welfare use can be approximated by a firstorder Markov model.

The model can be described as follows. Assume that individuals (indexed by $i$, $i=1,2, \ldots, n)$ who belong to one of three nativity groups (indexed by $m$, natives $(m=1)$, non-refugee immigrants $(m=2)$, and refugee immigrants $(m=3))$ choose between receiving welfare and not receiving welfare benefits in any time period $t(t=2,3, \ldots, T)$. Let the latent variable $y_{i m t}^{*}$, which represents the value for an individual $i$, who belongs to nativity group $m$, from receiving welfare benefits at time $t$, be specified as:

$$
\begin{aligned}
& y_{i m t}^{*}=\alpha_{m}+\mathbf{X}_{i m t} \beta_{m}+y_{i m t-1} \gamma_{m}+\varepsilon_{i m t} \\
& y_{i m t}=1\left(y_{i m t}^{*}>0\right)
\end{aligned}
$$

where $\mathbf{X}_{i m t}$ is a vector of observable characteristics, including time dummies, age, educational attainment, family composition, local unemployment rate, years since migration, arrival cohort dummies, and source country dummies. ${ }^{12} 1(\cdot)$ is an indicator function equal to one if the enclosed statement is true and zero otherwise, and $y_{i m t-1}$ is a dummy variable indicating if the individual received welfare in the previous time period or not.

The error term, $\varepsilon_{i m t}$, is assumed to have the following error-components structure:

$$
\varepsilon_{i m t}=\eta_{i m}+\nu_{i m t}
$$

where $\eta_{i m}$ represents an unobserved time-invariant individual specific effect and $\nu_{i m t}$ represents an error term and is assumed to be i.i.d. logistically distributed. ${ }^{13} \mathrm{We}$ also

\footnotetext{
${ }^{12}$ We define the following immigrant arrival cohorts; arrival before 1968, between 1968 and 1975, between 1976 and 1980, between 1981 and 1985, between 1986 and 1990 and arrival after 1990 .

${ }^{13}$ Note however that the permanent factor, $\eta$, allows for a particular form of serial correlation in $\varepsilon$.
} 
assume that $\mathbf{X}_{i m t}$ is strictly exogenous, conditional on $\eta_{i m}$, and that $\eta_{i m}$ is independent of $v_{\text {imkt }} \cdot{ }^{14}$ Given these assumptions, the probability that an individual $i$, from nativity group $m$, receives welfare at time $t$ is:

$$
P\left(y_{i m t}=1 \mid \mathbf{X}_{i m}, \eta_{i m}, y_{i m 1}, \ldots, y_{i m t-1}\right)=\exp \left(-\left[\alpha_{m}+\mathbf{X}_{i m t} \beta_{m}+y_{i m t-1} \gamma_{m}+\eta_{i m}\right]\right)^{-1}
$$

where $y_{i m 1}$ is an indicator of welfare recipiency in the initial sample period, and $\mathbf{X}_{i m} \equiv\left(\mathbf{X}_{i m 1}, \ldots, \mathbf{X}_{i m T}\right)$.

We follow Wooldridge (2005) and model the distribution of the unobserved effects conditional on the initial value of the dependent variable and any exogenous explanatory variables. ${ }^{15}$ The main advantage with this approach is that it relaxes the need to explicitly specify a distribution for the initial condition, and we can write the latent variable $y_{i m t}^{*}$, in this context as:

$$
\begin{aligned}
& y_{i m t}^{*}=\alpha_{m}+\mathbf{X}_{i m t} \beta_{m}+y_{i m t-1} \gamma_{m}+\varepsilon_{i m t} \\
& y_{i m t}=1\left(y_{i m t}^{*}>0\right)
\end{aligned}
$$

where

$$
\varepsilon_{i m t}=\eta_{i m}+\nu_{i m t}
$$

and

$$
\eta_{i m}=\mathbf{X}_{i m}^{*} \lambda_{m}+y_{i m 1} \rho_{m}+\kappa_{i m}
$$

\footnotetext{
${ }^{14}$ The strict exogeneity assumption implies, among other things, that feedback from the dependent variable on future values of the explanatory variables are ruled out. Arellano and Carrasco (2003) present and estimates models where this assumption is relaxed and the explanatory variables are instead predetermined. ${ }^{15}$ See also Arellano and Carrasco (2003) for a discussion of alternative model specifications in binary choice panel data models. We have also estimated specifications under alternative assumptions regarding the unobserved heterogeneity and initial conditions (a random-effects model with a probability distribution on the initial conditions and a fixed-effects model which makes no assumptions on unobserved heterogeneity and initial conditions). We found that the results on welfare persistence were similar across alternative model specifications. The results are presented in Tables A5-A10.
} 
where $\mathbf{X}_{i m}^{*}$ is a row vector of all non-redundant explanatory variables in all time periods, so $\mathbf{X}_{i} \equiv\left(\mathbf{X}_{i 0}, \ldots, \mathbf{X}_{i T}\right)$ defined above nests $\mathbf{X}_{i m}^{*}$. In this setup, the unobserved heterogeneity component, $\eta_{i m}$, is allowed to be correlated with $\mathbf{X}_{i m}^{*}$. Note however that the coefficients on time-invariant variables in $\mathbf{X}_{i m t}$ are not identified. The likelihood contribution for individual $i$ given observed characteristics and unobserved heterogeneity, can be written as:

$$
L_{i m}(\theta)=\int \prod_{\mathrm{t}=2}^{\mathrm{T}} P\left(y_{i m t} \mid y_{i m t-1}, y_{i m 1}, \mathbf{X}_{i m t}, \mathbf{X}_{i m t}^{*}, \kappa_{m}\right) \mathrm{g}\left(\kappa_{m}\right) \mathrm{d} \kappa_{m}
$$

We assume that the probability distribution of $\kappa_{i m}$ can be approximated by a discrete distribution with a finite number, $J$, of support points, in the spirit of Heckman and Singer (1984). Associated with each support point is a probability, $\pi_{j}$, where $\sum_{j=1}^{J} \pi_{j}=1$ and $\pi_{j} \geq 0$. Finally, we normalized the mean to zero, $\mathrm{E}\left(\kappa_{i m}\right)=0$, and the variance to one, $\operatorname{Var}\left(\kappa_{i m}\right)=1$. We experimented with different values for $J$, and found that a model with $J=2$ fitted the data quite well. ${ }^{16}$ This low dimensionality has been found in many studies of mixture models (e.g. Cameron and Heckman (2001), Ham and Lalonde (1996), and Eberwein, Ham and Lalonde (1997)).

\section{Empirical Results}

In this section, we present the results from estimating the two specifications of the dynamic welfare probability model: a "standard" logit with no unobserved effects and the dynamic random effects logit specification presented above, which we will refer to as the “correlated random effects” (CRE) specification. We focus our attention on the welfare dynamics, i.e. entry and exit probabilities. We first discuss the effects of modeling individual time invariant heterogeneity on the estimated transition probabilities. We also

\footnotetext{
${ }^{16}$ In a recent paper, Chay and Hyslop, 2000, estimate dynamic models of welfare use and labor force participation and find that the results regarding state dependence are not very sensitive to different distributional assumptions with respect to the unobserved heterogeneity.
} 
discuss the effects of entry and exit probabilities on welfare participation rates, particularly on the immigrant-native welfare utilization gap. The section ends with a discussion of the sensitivity of our results towards a number of assumptions, as well as a discussion of whether our findings can reasonably be generalized to other time periods.

\subsection{Estimated Entry and Exit Rates}

To obtain estimated entry and exit rates from welfare, we again follow Wooldridge (2005) and average out the distribution of the unobserved heterogeneity and compute estimated participation probabilities as;

$$
\widehat{\operatorname{Pr}}\left(y_{i m t}=1 \mid \mathbf{X}_{i m t}, \mathbf{X}_{i m t}^{*}, y_{i m t-1}, y_{i m 1}\right)=\mathrm{N}_{\mathrm{m}}^{-1} \sum_{\mathrm{i}=1}^{\mathrm{N}_{\mathrm{m}}} \exp \left(-\left[\widehat{\alpha}_{m}^{*}+\mathbf{X}_{i m t} \widehat{\beta}_{m}^{*}+y_{i m t-1} \hat{\gamma}_{m}^{*}+\mathbf{X}_{i m t}^{*} \hat{\lambda}_{m}^{*}+y_{i m 1} \hat{\rho}_{m}^{*}\right]\right)^{-1}
$$

where the parameter estimates in the estimated probabilities are divided by the estimated standard deviation of the total error variance. ${ }^{17}$ To illustrate the importance of controlling for endogenous initial conditions and unobserved heterogeneity, we present estimated transition rates for a standard logit specification in addition to those obtained from the CRE specification described in Section 5 above. For the standard logit specification, $\widehat{\lambda}_{m}^{*}$ and $\hat{\rho}_{\mathrm{m}}^{*}$ are set to 0 . To obtain estimates of the entry rate, we evaluate the equation above, setting $y_{i m t-1}$ to 0 ;

$\widehat{\operatorname{Pr}}\left(y_{i m t}=1 \mid \mathbf{X}_{i m t}, \mathbf{X}_{i m t}^{*}, y_{i m t-1}=0, y_{i m 1}\right)=\mathrm{N}_{\mathrm{m}}{ }^{-1} \sum_{\mathrm{i}=1}^{\mathrm{N}_{\mathrm{m}}} \exp \left(-\left[\widehat{\alpha}_{m}^{*}+\mathbf{X}_{i m t} \widehat{\beta}_{m}^{*}+\mathbf{X}_{i m t}^{*} \hat{\lambda}_{m}^{*}+y_{i m 1} \hat{\rho}_{m}^{*}\right]\right)^{-1}$

The estimates of the exit rate are obtained as;

$$
1-\widehat{\operatorname{Pr}}\left(y_{i m t}=1 \mid \mathbf{X}_{i m t}, \mathbf{X}_{i m t}^{*}, y_{i m t-1}=1, y_{i m 1}\right)
$$

\footnotetext{
${ }^{17}$ Full set of estimated parameters are available in Tables A5-A10 in Appendix.
} 
The estimated transition rates are presented in Table $3 .{ }^{18}$ For the standard logit model, which ignores the roles of unobserved heterogeneity and endogenous initial conditions, the estimated entry rate is 0.01 for native males, 0.025 for non-refugee males, 0.056 for refugee males, 0.009 for native females, 0.017 for non-refugee females, and 0.024 for refugee females. The estimated entry rates, which are similar to those presented in Table 2, suggest that the higher welfare participation rates among refugee immigrants, relative to natives, are partially due to higher incidences of entering welfare in any given time period, relative to natives.

When controls for endogenous initial conditions and time invariant unobserved heterogeneity are incorporated into the model, our CRE specification, we find significant increases in the estimated entry rates for all groups. The probability that a native male (female) initiates welfare receipt in any given time period increase from $0.010(0.009)$ in the simple logit specification to 0.014 (0.013) in the CRE specification. For male (female) immigrants from refugee countries, the estimated entry rate increases from $0.056(0.024)$ to $0.092(0.038)$. Thus, while the entry rates increased for all groups in the CRE specification, the difference in welfare entry rates between refugee immigrants and natives is higher than in the simple logit specification. The reason the entry rates increase in the CRE specification, relative to those found in the simple logit specification, is that the lagged dependent variable, $y_{i m t-1}$, is positively correlated with the unobserved heterogeneity term, $\eta_{i m}$. While the simple logit specification erroneously assumes that $\operatorname{Corr}\left(y_{i m t-1}, \eta_{i m}\right)=0$, the CRE specification allows $y_{i m t-1}$ and $\eta_{i m}$ to be correlated.

The estimated exit rates, also presented in Table 3, show that both male and female natives have higher probabilities of leaving welfare in any given time period than similarly endowed immigrants. Further, immigrants from non-refugee countries are more likely to leave welfare than refugee immigrants. This pattern holds regardless of estimation method. However, the simple logit model substantially underestimates the exit rates (and consequently overestimates persistence in welfare) for all groups. The difference in exit rates between the simple logit model and the CRE specification

\footnotetext{
${ }^{18}$ We obtained 5,000 draws from the asymptotic distribution of the maximum likelihood parameters and computed the transition rates for each draw. We subsequently calculated the standard errors as the standard deviation of the distribution of simulated values of the transition rates.
} 
highlights the fact that a substantial proportion of persistence in welfare is due to unobserved heterogeneity (e.g. labor market preferences, skills, disability, and/or any other time-invariant variables omitted from the set of observables). ${ }^{19}$

Overall, the estimated transition probabilities presented in Table 3 suggest that the immigrant-native gap in welfare use in Sweden is due to a combination of both higher entry rates and lower exit rates among immigrants. The results also point to the importance of controlling for endogenous initial conditions and time invariant unobserved heterogeneity, such as in the CRE specification. In specifications that ignore these issues, welfare entry and exit rates, as well as differences in immigrant-native welfare dynamics, are substantially underestimated.

\subsection{The Role of Observables and Transition Probabilities for the Immigrant- Native Welfare Participation Gap}

In this section we discuss the effects of entry and exit probabilities on welfare participation rates, particularly on the immigrant-native welfare utilization gap. In order to relate the transition probabilities, we assume that welfare participation is in steadystate and hence the welfare participation rate can be expressed as;

$$
\text { Welfare Participation Rate }=\frac{\text { Entry Rate }}{\text { Entry Rate }+ \text { Exit Rate }} .
$$

Utilizing the observed entry and exit rates, as shown in Table 3, under the assumption of welfare being in steady state, the "implied" welfare participation rates are approximately 3, 7 and 16 percent respectively for native, non-refugee and refugee males respectively. For all three groups, the implied welfare participation rates are somewhat below the observed average participation rates, which also hold for women. A plausible reason for the differences between the average observed and the implied participation rates is that the observed welfare participation rates changes, mostly declined, over the

\footnotetext{
${ }^{19}$ The economics literature (e.g. Heckman (1981), Chay and Hyslop (2000), Hansen and Lofstrom (2001)) generally distinguish between true (or structural) persistence, in which past participation has a causal effect on current participation, and spurious persistence, in which there is no causal effect of past participation.
} 
sample period. The unadjusted welfare participation gaps for men are 4.4 percent and 12.9 percent for immigrants from non-refugee and refugee countries respectively. The unadjusted gaps among women are substantially smaller, about $1 / 2$ of the respective immigrant-native male gaps.

The implied welfare participation rates and immigrant-native participation gaps, based on transition rates under different scenarios, are shown in Table 4. All simulations are based on the CRE estimates. Compared to the unadjusted differences in welfare participation, the predicted gaps among males drop by about one percentage points when we use the predictions based on parameters from the CRE specifications. For women, the immigrant-native gap is reduced by about one half of a percentage point for non-refugees and by approximately 1.5 percentage points for female immigrants from refugee countries.

We also analyze the gaps under the assumption of immigrants experiencing the native entry and exit rates separately. The predicted welfare participation gaps are very small, less than one percentage points for all groups, under the hypothetical scenario in which immigrant entry rates are those predicted of natives, maintaining immigrants’ predicted exit rates. Table 4 shows that the participation gaps are substantially greater under the alternative hypothetical, in which immigrants experience natives' predicted exit rates. Now, the gap for male non-refugees is close to 3 percent, while it is slightly more than 7 percent for male refugees. These simulations strongly suggest that the welfare participation gap is predominantly caused by differences in entry rates, as opposed to exit rates, although both transition rates contribute to immigrant-native welfare participation gap.

The role of differences between immigrants and natives in observable characteristics is also addressed in Table 4. We predict immigrant entry and exit rates utilizing the estimated immigrant CRE parameter vector while using native sample means. The simulations suggest that differences in observables is not the main contributing factor in explaining welfare utilization differences between immigrants and natives. In fact, it appears that differences in our observable controls between male natives and refugees explain only about 3 percent of the welfare participation gap. Differences in observables between male natives and male non-refugee immigrants 
appears to contribute meaningfully to the welfare participation gap, approximately 20 percent is explained by these differences. Similarly, slightly less that 20 percent of the female refugee immigrant-native welfare participation gap is due to differences in observables. Roughly 2/3 of the small, 1.5 percentage points, female non-refugee-native welfare gap appears to be due to differences in the observables. The results in Table 4 also suggest that it is immigrant-native difference in the observables of welfare entrants and non-entrants that contribute relatively more to explaining differences in welfare utilization between immigrants and natives.

\subsection{Results from Alternative Model Specifications}

The empirical analysis presented above is based on data where the dependent variable equals one if a person received social assistance for at least one month during the year, and equals zero otherwise. However, it may be the case that social assistance serves as a form of unemployment insurance (UI) for certain groups who have not yet established themselves on the labor market, such as recent immigrants, as well as young natives, and therefore are not covered by the traditional UI system in Sweden.

To explore if our estimated results of differences in transition rates between natives and immigrants, as well as the role of these rates on the immigrant-native welfare participation gap, are sensitive towards the definition of the dependent variable, we reestimated the CRE models using a different definition of welfare participation. In this alternative definition, individuals are defined to be participants if they received social assistance and/or unemployment insurance during the year. The results from the application of this alternative definition are presented in Table 5. As expected, the entry rates increase for all groups. For instance, for native males, the probability of initiating welfare and/or UI is 0.05 , about 3.6 times higher than the entry rate for welfare only. For male refugees, the entry rate increase from 0.092 to 0.176 . The exit rates are also significantly affected by the definition of welfare participation. For all groups, the exit rates decrease substantially. For native males, the exit rate decrease from 0.924 to 0.59 and for refugee males, the exit rate drop from 0.61 to 0.372 . 
Overall, these results suggest that transition rates in welfare participation are dependent on how we define welfare use. Using the broader definition, not surprisingly, we find a higher incidence of initiating welfare and a lower probability of leaving welfare for all groups. However, although the transition rates are significantly affected, our results concerning the role of entry and exit rates on the immigrant-native welfare participation gaps remain largely the same. In Table 6, we present predicted participation rates as well as differences in participation between natives and immigrants from nonrefugee and refugee countries, respectively. The participation rates are predicted in the same way as in Section 6.2 above (i.e. assuming steady-state). Both the simulated participation rates and the implied immigrant-native participation gaps increase using our broader welfare definition. The predicted participation rates in welfare and/or UI is highest for refugee males, 32 percent, and lowest for native females, slightly below 8 percent. Assuming native entry rates in generating participation rates for immigrants yield substantially lower predicted participation rates and immigrant-native participation gaps. For example, if non-refugee immigrants faced the same entry probabilities as natives, maintaining differences in exit rates, the estimated difference in welfare participation between this group and natives would essentially disappear, the simulated gap is 0.004 for males and 0.002 for females. These results closely resemble our findings in Section 6.2. We obtain similar results for refugee immigrants, with a substantial reduction in the welfare gap. However, a non-negligible gap remains even after assuming native entry rates.

If we instead use natives' exit rate in generating participation rates for immigrants, the immigrant-native participation gaps remains quite large, especially for refugee immigrants. This result is also consistent with our findings above, and indicates that a major reason for differences in welfare use between immigrants and natives are the relatively large differences in probabilities of entering welfare.

To further examine the robustness of our results, we estimated specifications of the logit model under alternative assumptions regarding the unobserved heterogeneity and initial conditions. We considered a random-effects model with a probability distribution on the initial conditions, following Heckman (1981) and a fixed-effects logit model, which makes no assumptions on unobserved heterogeneity and initial conditions, 
following Honore and Kyriazidou (2000). We find that the estimates on the lagged dependent variable, crucial for estimating transition rates, in these alternative specifications were similar to those obtained in the CRE specification. ${ }^{20}$ Hence, we believe that our results are not driven by convenient stochastic assumptions on the initial conditions or unobserved heterogeneity. ${ }^{21}$

\subsection{Can the Results Be Generalized to Recently Arrived Refugees?}

The results thus far provide convincing evidence that differences in welfare participation between immigrants and natives are largely due to differences in welfare entry rates. However, because of the balanced nature of the panel used in all estimations above, recent immigrants, in particular recent refugee immigrants, who arrived in Sweden during the 1990's, are excluded from the analysis. To address the issue of the effect of changes in the composition of refugees, we re-estimated the CRE model utilizing an alternative sample of refugee immigrants. In this sample, we reduce the length of the panel and only consider information for the years 1996 to 2001. This implies that refugees who arrived in the early 1990's, a period when a large number of refugees who currently reside in Sweden arrived, are included in the sample.

Using this shorter panel, we estimated the transition probabilities for two groups of male refugee immigrants, one group consisting of those who arrived in Sweden prior to 1991, and the other group consisting of refugees who arrived between 1991 and 1994 . The estimated entry (exit) rate for the former group is 0.073 (0.635). For the latter group, the entry rate is significantly larger, 0.181 , and the exit rate is significantly lower, 0.278. The implied predicted participation probability for recent refugee immigrants is 0.394 , substantially higher than that predicted for all male refugee immigrants, 0.131 . When we use natives' entry rates for recent refugee immigrants the implied participation rate drop

\footnotetext{
${ }^{20}$ The results are presented in Tables A5-A10.

${ }^{21}$ We also assessed model fit by using predicted frequencies and compared them to the observed frequencies of welfare participation. We report predicted, based on the CRE specification, and observed year specific participation rates for males for the period 1992-2001, by nativity group, in Table A11. The results for females are shown in Table A12. The predicted distributions were calculated for each year between 1992 and $2001(\mathrm{t}=2, \ldots, 11)$. Overall, the predicted frequencies are quite similar to the observed frequencies indicating that the empirical models fit the observed distributions quite well.
} 
to 0.048 , a reduction of 34.6 percentage points. Using natives’ exit rates instead reduce the implied participation rate to 0.164 .

A potential explanation for the difference in welfare participation between the two refugee groups is the fact that recent immigrants have had less time to establish themselves on the labor market. Following the discussion above, they might not be covered by the traditional unemployment system and therefore need to rely on welfare for their subsistence. To assess the effects of being new on the labor market, we re-estimated the CRE model utilizing a sample consisting of native males who were less than 25 years of age in 1991. The estimated entry rate probability for this sample of young native males, who are relatively new labor market entrants, is 0.0314 or close to three times as larges as the estimated entry rate probability for the full sample of native males. Thus, welfare entry rates appear to be negatively correlated with time spent on the labor market. The estimated exit rates appear not to be as sensitive to “newness' on the labor market. Our estimated exit rate probability for the sample of young males is slightly lower than the full sample exit rates, 0.855 and 0.924 respectively. These results suggests that one reason for the finding of higher welfare reliance among refugee immigrants may be that they are more likely to be relatively new entrants on the Swedish labor market and that this effect operates primarily through the entry rate probability.

\section{Summary and Conclusions}

This paper analyzes transitions into and out of social assistance. We use data from a large representative Swedish panel data set, LINDA, for the years 1991 to 2001, to investigate if there are differences in welfare transition probabilities between immigrants and natives. The unadjusted data indicates that immigrants are significantly more likely to receive welfare than natives. The raw data also suggest that immigrants are more likely to enter welfare and less likely to leave welfare in any given time period than natives. The immigrant-native differences are especially large for immigrants from refugee countries. 
The empirical results suggest that the main reason for the immigrant-native welfare gap is differences in welfare entry rates. When using natives' estimated entry rates in predicting welfare participation for immigrants, we found that the welfare gap diminished substantially. While using natives’ estimated exit rates also reduced the gap, the reduction was substantially smaller. Our results also indicate that immigrant-native differences in observable characteristics are not the main contributors to the immigrantnative welfare gap.

One potential reason for the observed difference in welfare participation between immigrants and natives is that welfare may serve as a form of unemployment insurance (UI) for certain groups who have not yet established themselves on the labor market, such as recent immigrants, and therefore are not covered by the traditional UI system. We explored this issue by considering an alternative definition of welfare that also includes the use of UI, and by comparing outcomes of different arrival cohorts of refugee immigrants. While the estimated transition rates were affected, the conclusion that the relatively higher immigrant welfare participation rates are primarily due to differences in welfare entrance still hold. Overall, our results appear to be robust towards different definitions of welfare use, different econometric specifications, and different arrival cohorts of immigrants.

Our results strongly indicate that the main route to reduce the immigrant-native welfare gap is to focus on reducing the probability, and need, of initiating welfare among immigrants. Possible policies that may address welfare entries, and welfare exits as well, include provision of employment and training for employable applicants. An advantage of training policies is that they may have long term beneficial consequences due to their human capital enhancing effect. The effectiveness of such policies, particularly for immigrants, is not addressed in this paper but is of great interest for future research. Other policies that may particularly affect entry into reliance on welfare are welfare eligibility waiting time, time limits and generosity. Unfortunately, by definition these policies decrease the economic well-being of welfare participants, an obvious concern when addressing the situation of individuals in a precarious situation, such as refugee immigrants. 
An important question is what are the key determinants of immigrant and native differences in welfare utilization. Our results indicate that differences in observable characteristics play a relatively minor role. Not surprisingly, one observable factor that matters differently for men and women is family composition. Our results suggest that single parenthood is a key female welfare participation determinant, particularly regarding welfare exits. We also find that immigrant men are more sensitive to changes in the local labor market conditions than native men, consistent with Lofstrom and Bean's (2002) finding for the U.S. This, at least partially, explains the narrowing in the welfare participation gap observed in the latter part of the 1990s and early 2000s in Sweden.

Our results indicate that time invariant individual unobserved heterogeneity plays an important role in explaining individual welfare behavior, as well as in explaining differences between immigrants and natives. What the unobservables represent is on the other hand difficult to assess. However, our approach, and model specification, allows for the unobserved heterogeneity to represent different factors between the groups. It is possible for example that for natives, important unobserved factors are long term work disability and preferences while for refugees the unobserved heterogeneity may represent proficiency in the Swedish language or country specific human capital. The unobserved heterogeneity may also vary across gender.

Although policies aimed at reducing welfare entries may reduce the immigrantwelfare participation gap, our results also indicate that part of the gap, particularly the refugee-native gap, is due to a large share of refugees in Sweden are relatively new labor market entrants and that new labor market entrants in particular display relatively high welfare entry rates and relatively low exit rates. Consistent with Hansen and Lofstrom (2003), this suggests that the gap will be reduced as immigrants spend more time in the new host country.

Finally, it is important discuss whether our results can be generalized to other countries. Although certain aspects of both immigration and the structure of the welfare system are likely to be unique to Sweden, there are also many similarities in terms of the composition of immigrants, the support system for recently arrived refugee immigrants, and the difficulties faced by immigrants in the host country's labor market. These 
similarities suggest that our results are informative and useful to the immigration and welfare debate in other countries. 


\section{References}

Arellano, Manuel and Carrasco, Raquel, "Binary Panel Data Models with Predetermined Variables,” Journal of Econometrics, 115(1), 2003, 125-157.

Baker, Michael and Benjamin, Dwayne, “The Receipt of Transfer Payments by Immigrants to Canada,” Journal of Human Resources, 30(4), 1995, 650-676.

Bauer, Thomas, Lofstrom, Magnus and Zimmermann, Klaus F., “Immigration Policy, Assimilation of Immigrants, and Natives' Sentiments towards Immigrants: Evidence from 12 OECD Countries,” Swedish Economic Policy Review, 7(2), 2000, 11-53.

Borjas, George J. and Hilton, Lynette, "Immigration and the Welfare State: Immigrant Participation in means-tested Entitlement Programs”, Quarterly Journal of Economics 111(2), 1996, 575-604.

Cameron, Stephen and Heckman, James, “The Dynamics of Educational Attainment for Black, Hispanic, and White Males,” Journal of Political Economy, 109(3), 2001, 455-499.

Chay, Kenneth Y and Hyslop, Dean. "Identification and Estimation of Dynamic Binary Response Panel Data Models: Empirical Evidence using Alternative Approaches,” Working paper, UC Berkeley, 2000.

Eberwein, Curtis, Ham, John and Lalonde, Robert, “The Impact of Being Offered and Receiving Classroom Training on the Employment Histories of Disadvantaged Women: Evidence from Experimental Data," Review of Economic Studies, 64(4), 1997, 655-682.

Edin, Per-Anders and Fredriksson, Peter, “LINDA-Longitudinal Individual Data for Sweden,” Working Paper, Uppsala University, Department of Economics, 2000.

Ham, John and Lalonde, Robert, "The Effect of Sample Selection and Initial Conditions in Duration Models: Evidence from Experimental Data on Training,” Econometrica, 64(1), 1996, 175-205.

Hansen, Jorgen and Lofstrom, Magnus "Immigrant Assimilation and Welfare Participation: Do Immigrants Assimilate Into or Out-of Welfare?” Journal of Human Resources, forthcoming, 38(1), 2003.

Hansen, Jorgen and Lofstrom, Magnus “The Dynamics of Immigrant Welfare and Labor Market Behavior”, IZA Discussion Paper No. 360, August 2001. 
Heckman, James "The Incidental Parameters Problem and the Problem of Initial Conditions in Estimating a Discrete Time-Discrete Data Stochastic Process,” in Structural Analysis of Discrete Data with Econometric Applications, eds. Manski, C. and D. McFadden, MIT Press, London, 1981,114-179.

Heckman, James and Singer, Burton "A Method for Minimizing the Impact of Distributional Assumption in Econometric Models for Duration Data," Econometrica, March, 1984, 271-320.

Honore, Bo and Kyriazidou, Ekaterini, "Panel Data Discrete Choice Models with Lagged Dependent Variables," Econometrica, 68(4), 2000, 839-874.

Lofstrom, Magnus and Frank D. Bean, “Assessing Immigrant Policy Options: Labor Market Conditions and Post-Reform Declines in Welfare Receipt Among Immigrants,” Demography, forthcoming, 39(4), November 2002.

Plant, Mark W., “An Empirical Analysis of Welfare Dependence,” American Economic Review, 74(4), 1984, 673-684.

Riphanh, Regina T. "Immigrant Participation in Social Assistance Programs: Evidence from German Guestworkers,” IZA Discussion Paper No. 15, July 1998.

SOPEMI: Trends in International Migration, 2000, Paris: OECD.

SOPEMI: Trends in International Migration, 2003, Paris: OECD.

Van Ours, Jan C. and Justus Veenman. "The Netherlands: Old Emigrants - Young Immigrant Country”, IZA Discussion Paper No. 80, December 1999.

Wooldridge, Jeffrey M., "Simple Solutions to the Initial Conditions Problem in Dynamic, Nonlinear Panel Data Models with Unobserved Heterogeneity," Journal of Applied Econometrics, 20(1), 2005, 39-54. 
Table 1.

Mean Observable Characteristics, 1991-2001, by Immigrant Group and Gender, Balanced Panel.

\begin{tabular}{|c|c|c|c|}
\hline & \multirow[b]{2}{*}{ Natives } & \multicolumn{2}{|c|}{ Immigrants } \\
\hline & & Non-Refugee & Refugee \\
\hline & \multicolumn{3}{|c|}{ Men } \\
\hline Age & 44.46 & 44.09 & 40.65 \\
\hline Elementary School (Dummy) & 0.271 & 0.361 & 0.302 \\
\hline High School (Dummy) & 0.486 & 0.448 & 0.461 \\
\hline College (Dummy) & 0.243 & 0.191 & 0.237 \\
\hline Large City Resident (Dummy) & 0.310 & 0.510 & 0.646 \\
\hline Medium City Resident (Dummy) & 0.447 & 0.302 & 0.276 \\
\hline Married (Dummy) & 0.664 & 0.580 & 0.623 \\
\hline Number of Household Members & 2.65 & 2.51 & 2.89 \\
\hline Children (Dummy) & 0.423 & 0.394 & 0.510 \\
\hline Number of Children in Household & 0.79 & 0.75 & 1.09 \\
\hline Number of Adults in Household & 1.86 & 1.76 & 1.80 \\
\hline Years Since Immigrated & N/A & 19.58 & 12.92 \\
\hline Welfare Participation (\%) & 3.14 & 8.17 & 20.21 \\
\hline Welfare and/or UI Participation (\%) & 12.14 & 18.97 & 37.82 \\
\hline \multirow[t]{2}{*}{ Number of Households } & 43,374 & 2,030 & 1,786 \\
\hline & \multicolumn{3}{|c|}{ Women } \\
\hline Age & 44.44 & 42.94 & 41.13 \\
\hline Elementary School (Dummy) & 0.220 & 0.312 & 0.336 \\
\hline High School (Dummy) & 0.508 & 0.454 & 0.416 \\
\hline College (Dummy) & 0.272 & 0.235 & 0.248 \\
\hline Large City Resident (Dummy) & 0.316 & 0.502 & 0.609 \\
\hline Medium City Resident (Dummy) & 0.448 & 0.319 & 0.284 \\
\hline Married (Dummy) & 0.685 & 0.619 & 0.673 \\
\hline Number of Household Members & 2.75 & 2.78 & 3.16 \\
\hline Children (Dummy) & 0.452 & 0.507 & 0.630 \\
\hline Number of Children in Household & 0.83 & 0.90 & 1.21 \\
\hline Number of Adults in Household & 1.92 & 1.88 & 1.95 \\
\hline Years Since Immigrated & $\mathrm{N} / \mathrm{A}$ & 19.62 & 13.70 \\
\hline Welfare Participation (\%) & 2.74 & 4.93 & 9.37 \\
\hline Welfare and/or UI Participation (\%) & 12.00 & 15.76 & 28.04 \\
\hline Number of Households & 41,628 & 2,003 & 1,402 \\
\hline
\end{tabular}


Table 2.

Transition Matrices, Conditional Probabilities of Welfare/Unemployment

Receipt for the Period 1991-2001, by Immigrant Group and Gender, Balanced Panel.

\begin{tabular}{|c|c|c|c|c|}
\hline & \multicolumn{2}{|r|}{ Men } & \multicolumn{2}{|c|}{ Women } \\
\hline & \multicolumn{4}{|c|}{ Natives } \\
\hline Welfare $_{t-1}$ & $\begin{array}{c}\text { Welfare }_{t} \\
0.624 \\
(0.0068)\end{array}$ & $\begin{array}{c}\text { Not on Welfare } \\
0.376 \\
(0.0041)\end{array}$ & $\begin{array}{c}\text { Welfare }_{t} \\
0.611 \\
(0.0070)\end{array}$ & $\begin{array}{c}\text { Not on Welfare } \\
0.389 \\
(0.0045)\end{array}$ \\
\hline Not on Welfare ${ }_{t-1}$ & $\begin{array}{c}0.011 \\
(0.0002)\end{array}$ & $\begin{array}{c}0.989 \\
(0.0145)\end{array}$ & $\begin{array}{c}0.009 \\
(0.0002)\end{array}$ & $\begin{array}{c}0.991 \\
(0.0159)\end{array}$ \\
\hline UI/Welfare ${ }_{t-1}$ & $\begin{array}{c}\text { UI/Welfare }_{t} \\
0.744 \\
(0.0054)\end{array}$ & $\begin{array}{c}\text { Not on UI/Welfare }{ }_{t} \\
0.257 \\
(0.0019)\end{array}$ & $\begin{array}{c}\text { UI/Welfare }_{t} \\
0.726 \\
(0.0052)\end{array}$ & $\begin{array}{c}\text { Not on UI/Welfare } \\
0.274 \\
(0.0020)\end{array}$ \\
\hline \multirow[t]{2}{*}{ Not on UI/Welfare ${ }_{t-1}$} & $\begin{array}{c}0.038 \\
(0.0003)\end{array}$ & $\begin{array}{c}0.962 \\
(0.0078)\end{array}$ & $\begin{array}{c}0.041 \\
(0.0003)\end{array}$ & $\begin{array}{c}0.959 \\
(0.0077)\end{array}$ \\
\hline & \multicolumn{4}{|c|}{ Non-Refugee Immigrants } \\
\hline Welfare $_{\mathrm{t}-1}$ & $\begin{array}{c}\text { Welfare }_{\mathrm{t}} \\
0.655 \\
(0.0217)\end{array}$ & $\begin{array}{c}\text { Not on Welfare } \\
0.345 \\
(0.0115)\end{array}$ & $\begin{array}{c}\text { Welfare }_{t} \\
0.609 \\
(0.0236)\end{array}$ & $\begin{array}{c}\text { Not on Welfare } \\
0.391 \\
(0.0151)\end{array}$ \\
\hline Not on Welfare ${ }_{t-1}$ & $\begin{array}{c}0.027 \\
(0.0012)\end{array}$ & $\begin{array}{c}0.973 \\
(0.0433)\end{array}$ & $\begin{array}{c}0.017 \\
(0.0009)\end{array}$ & $\begin{array}{c}0.983 \\
(0.0549)\end{array}$ \\
\hline & UI/Welfare $_{t}$ & Not on UI/Welfare ${ }_{t}$ & UIIWelfare $_{t}$ & Not on UI/Welfare ${ }_{t}$ \\
\hline UI/Welfare $\mathrm{t}_{\mathrm{t}-1}$ & $\begin{array}{c}0.765 \\
(0.0219)\end{array}$ & $\begin{array}{c}0.235 \\
(0.0067)\end{array}$ & $\begin{array}{c}0.722 \\
(0.0204)\end{array}$ & $\begin{array}{c}0.278 \\
(0.0078)\end{array}$ \\
\hline \multirow[t]{2}{*}{ Not on UI/Welfare ${ }_{t-1}$} & $\begin{array}{c}0.053 \\
(0.0018)\end{array}$ & $\begin{array}{c}0.947 \\
(0.0313)\end{array}$ & $\begin{array}{c}0.053 \\
(0.0017)\end{array}$ & $\begin{array}{c}0.947 \\
(0.0308)\end{array}$ \\
\hline & \multicolumn{4}{|c|}{ Refugee Immigrants } \\
\hline Welfare $_{t-1}$ & $\begin{array}{c}\text { Welfare }_{t} \\
0.716 \\
(0.0185)\end{array}$ & $\begin{array}{c}\text { Not on Welfare } \\
0.284 \\
(0.0073)\end{array}$ & $\begin{array}{c}\text { Welfare }_{t} \\
0.709 \\
(0.0299)\end{array}$ & $\begin{array}{c}\text { Not on Welfare } \\
0.291 \\
(0.0123)\end{array}$ \\
\hline Not on Welfare ${ }_{t-1}$ & $\begin{array}{c}0.053 \\
(0.0019)\end{array}$ & $\begin{array}{c}0.947 \\
(0.0338)\end{array}$ & $\begin{array}{c}0.023 \\
(0.0013)\end{array}$ & $\begin{array}{c}0.977 \\
(0.0561)\end{array}$ \\
\hline UI/Welfare $_{t-1}$ & $\begin{array}{c}\text { UI/Welfare }_{t} \\
0.816 \\
(0.0206)\end{array}$ & $\begin{array}{c}\text { Not on UI/Welfare }{ }_{t} \\
0.184 \\
(0.0046)\end{array}$ & $\begin{array}{c}\text { UI/Welfare }_{t} \\
0.773 \\
(0.0224)\end{array}$ & $\begin{array}{c}\text { Not on UI/Welfare } \\
0.227 \\
(0.0066)\end{array}$ \\
\hline Not on UI/Welfare ${ }_{t-1}$ & $\begin{array}{c}0.099 \\
(0.0029)\end{array}$ & $\begin{array}{c}0.901 \\
(0.0261)\end{array}$ & $\begin{array}{c}0.091 \\
(0.0029)\end{array}$ & $\begin{array}{c}0.909 \\
(0.0287)\end{array}$ \\
\hline
\end{tabular}

Note: Standard errors in parentheses. 
Table 3.

Estimated Welfare Entry and Exit Probabilities, by Immigrant Group and Gender.

\begin{tabular}{|c|c|c|c|c|}
\hline & $\begin{array}{c}\text { Entry } \\
\text { Probability }\end{array}$ & $\begin{array}{c}\text { Exit } \\
\text { Probability }\end{array}$ & $\begin{array}{c}\text { Entry } \\
\text { Probability }\end{array}$ & $\begin{array}{c}\text { Exit } \\
\text { Probability }\end{array}$ \\
\hline & \multicolumn{2}{|c|}{ Men } & \multicolumn{2}{|c|}{ Women } \\
\hline Specification & \multicolumn{4}{|c|}{ Natives } \\
\hline Observed & $\begin{array}{c}0.011 \\
(0.0002)\end{array}$ & $\begin{array}{c}0.376 \\
(0.0041)\end{array}$ & $\begin{array}{c}0.009 \\
(0.0002)\end{array}$ & $\begin{array}{c}0.389 \\
(0.005)\end{array}$ \\
\hline Logit & $\begin{array}{c}0.010 \\
(0.0002)\end{array}$ & $\begin{array}{c}0.575 \\
(0.0050)\end{array}$ & $\begin{array}{c}0.009 \\
(0.0002)\end{array}$ & $\begin{array}{c}0.761 \\
(0.004)\end{array}$ \\
\hline CRE & $\begin{array}{c}0.014 \\
(0.0003)\end{array}$ & $\begin{array}{c}0.924 \\
(0.0021)\end{array}$ & $\begin{array}{c}0.013 \\
(0.0003)\end{array}$ & $\begin{array}{c}0.941 \\
(0.002)\end{array}$ \\
\hline & \multicolumn{4}{|c|}{ Non-Refugee Immigrants } \\
\hline Observed & $\begin{array}{c}0.027 \\
(0.0012)\end{array}$ & $\begin{array}{c}0.345 \\
(0.0115)\end{array}$ & $\begin{array}{c}0.017 \\
(0.0009)\end{array}$ & $\begin{array}{c}0.391 \\
(0.015)\end{array}$ \\
\hline Logit & $\begin{array}{c}0.025 \\
(0.0012)\end{array}$ & $\begin{array}{c}0.465 \\
(0.0143)\end{array}$ & $\begin{array}{c}0.017 \\
(0.0010)\end{array}$ & $\begin{array}{c}0.678 \\
(0.015)\end{array}$ \\
\hline CRE & $\begin{array}{c}0.043 \\
(0.0023)\end{array}$ & $\begin{array}{c}0.828 \\
(0.0111)\end{array}$ & $\begin{array}{c}0.027 \\
(0.0018)\end{array}$ & $\begin{array}{c}0.897 \\
(0.009)\end{array}$ \\
\hline & \multicolumn{4}{|c|}{ Refugee Immigrants } \\
\hline Observed & $\begin{array}{c}0.053 \\
(0.0019)\end{array}$ & $\begin{array}{c}0.284 \\
(0.0073)\end{array}$ & $\begin{array}{c}0.023 \\
(0.0013)\end{array}$ & $\begin{array}{c}0.291 \\
(0.012)\end{array}$ \\
\hline Logit & $\begin{array}{c}0.056 \\
(0.0021)\end{array}$ & $\begin{array}{c}0.359 \\
(0.0092)\end{array}$ & $\begin{array}{c}0.024 \\
(0.0015)\end{array}$ & $\begin{array}{c}0.454 \\
(0.017)\end{array}$ \\
\hline CRE & $\begin{array}{c}0.092 \\
(0.0040)\end{array}$ & $\begin{array}{c}0.610 \\
(0.0121)\end{array}$ & $\begin{array}{c}0.038 \\
(0.0027)\end{array}$ & $\begin{array}{c}0.745 \\
(0.019)\end{array}$ \\
\hline
\end{tabular}

Note: Standard errors in parentheses. 
Table 4.

Steady-State Welfare Predictions and Immigrant-Native Participation Gaps.

\begin{tabular}{|c|c|c|c|c|}
\hline & Non-Refugee & Refugee & Non-Refugee & Refugee \\
\hline & \multicolumn{2}{|c|}{ Men } & \multicolumn{2}{|c|}{ Women } \\
\hline & \multicolumn{4}{|c|}{ Predictions with Group Specific Estimates and Observables } \\
\hline Participation & 0.049 & 0.131 & 0.029 & 0.048 \\
\hline \multirow[t]{2}{*}{ Gap (Immigrant-Native) } & 0.034 & 0.116 & 0.015 & 0.034 \\
\hline & \multicolumn{4}{|c|}{ Predictions Assuming Native Entry Rate } \\
\hline Participation & 0.017 & 0.022 & 0.015 & 0.017 \\
\hline \multirow[t]{2}{*}{ Gap (Immigrant-Native) } & 0.002 & 0.008 & 0.001 & 0.004 \\
\hline & \multicolumn{4}{|c|}{ Predictions Assuming Native Exit Rate } \\
\hline Participation & 0.044 & 0.090 & 0.028 & 0.038 \\
\hline \multirow[t]{2}{*}{ Gap (Immigrant-Native) } & 0.029 & 0.076 & 0.014 & 0.024 \\
\hline & \multicolumn{4}{|c|}{ Predictions Based on Native Sample Means } \\
\hline Predicted & \multicolumn{4}{|c|}{ Using Entry Rate Predictions } \\
\hline Participation & 0.038 & 0.130 & 0.017 & 0.043 \\
\hline Gap (Immigrant-Native) & 0.023 & 0.115 & 0.003 & 0.029 \\
\hline Predicted & \multicolumn{4}{|c|}{ Using Exit Rate Predictions } \\
\hline Participation & 0.054 & 0.129 & 0.032 & 0.048 \\
\hline Gap (Immigrant-Native) & 0.039 & 0.114 & 0.018 & 0.034 \\
\hline Predicted & \multicolumn{4}{|c|}{ Using Both Entry and Exit Rate Predictions } \\
\hline Participation & 0.042 & 0.128 & 0.019 & 0.042 \\
\hline Gap (Immigrant-Native) & 0.027 & 0.113 & 0.005 & 0.028 \\
\hline
\end{tabular}

Note: In steady-state, the welfare participation rate is equal to Entry rate / (Entry rate + Exit rate). All predictions utilize correlated random effects (CRE) estimates. 
Table 5.

Estimated Welfare Entry and Exit Probabilities, by Immigrant Group and Gender, Alternative Dependent Variable; Welfare and/or UI

\begin{tabular}{|c|c|c|c|c|}
\hline & $\begin{array}{c}\text { Entry } \\
\text { Probability }\end{array}$ & $\begin{array}{c}\text { Exit } \\
\text { Probability }\end{array}$ & $\begin{array}{c}\text { Entry } \\
\text { Probability }\end{array}$ & $\begin{array}{c}\text { Exit } \\
\text { Probability }\end{array}$ \\
\hline & \multicolumn{2}{|c|}{ Men } & \multicolumn{2}{|c|}{ Women } \\
\hline Welfare and/or UI & $\begin{array}{c}0.05 \\
(0.001)\end{array}$ & $\begin{array}{c}0.59 \\
(0.005)\end{array}$ & $\begin{array}{l}0.052 \\
(0.001)\end{array}$ & $\begin{array}{c}0.631 \\
(0.004)\end{array}$ \\
\hline Welfare and/or UI & $\begin{array}{c}0.086 \\
(0.003)\end{array}$ & $\begin{array}{c}\text { Non-Refug } \\
0.56 \\
(0.015)\end{array}$ & $\begin{array}{c}\text { mmigrants } \\
0.077 \\
(0.003)\end{array}$ & $\begin{array}{c}0.616 \\
(0.014)\end{array}$ \\
\hline Welfare and/or UI & $\begin{array}{c}0.176 \\
(0.006)\end{array}$ & $\begin{array}{c}\text { Refugee } \\
0.372 \\
(0.010)\end{array}$ & $\begin{array}{c}\text { nigrants } \\
0.136 \\
(0.005)\end{array}$ & $\begin{array}{c}0.445 \\
(0.014)\end{array}$ \\
\hline
\end{tabular}

Table 6.

Steady-State Welfare Predictions and Immigrant-Native Participation Gaps, Alternative Dependent Variable; Welfare and/or UI

\begin{tabular}{|c|c|c|c|c|}
\hline & Non-Refugee & Refugee & Non-Refugee & Refugee \\
\hline & \multicolumn{2}{|c|}{ Men } & \multicolumn{2}{|c|}{ Women } \\
\hline & \multicolumn{4}{|c|}{ Predictions with Group Specific Estimates and Observables } \\
\hline Participation & 0.133 & 0.321 & 0.111 & 0.234 \\
\hline \multirow[t]{2}{*}{ Gap (Immigrant-Native) } & 0.055 & 0.243 & 0.035 & 0.158 \\
\hline & \multicolumn{4}{|c|}{ Predictions Assuming Native Entry Rate } \\
\hline Participation & 0.082 & 0.118 & 0.078 & 0.105 \\
\hline \multirow[t]{2}{*}{ Gap (Immigrant-Native) } & 0.004 & 0.040 & 0.002 & 0.028 \\
\hline & \multicolumn{4}{|c|}{ Predictions Assuming Native Exit Rate } \\
\hline Participation & 0.127 & 0.230 & 0.109 & 0.177 \\
\hline Gap (Immigrant-Native) & 0.049 & 0.152 & 0.033 & 0.101 \\
\hline
\end{tabular}


Figure 1. Average Annual Unemployment Rates 1991-2001,Males and Females, Ages 16-64.

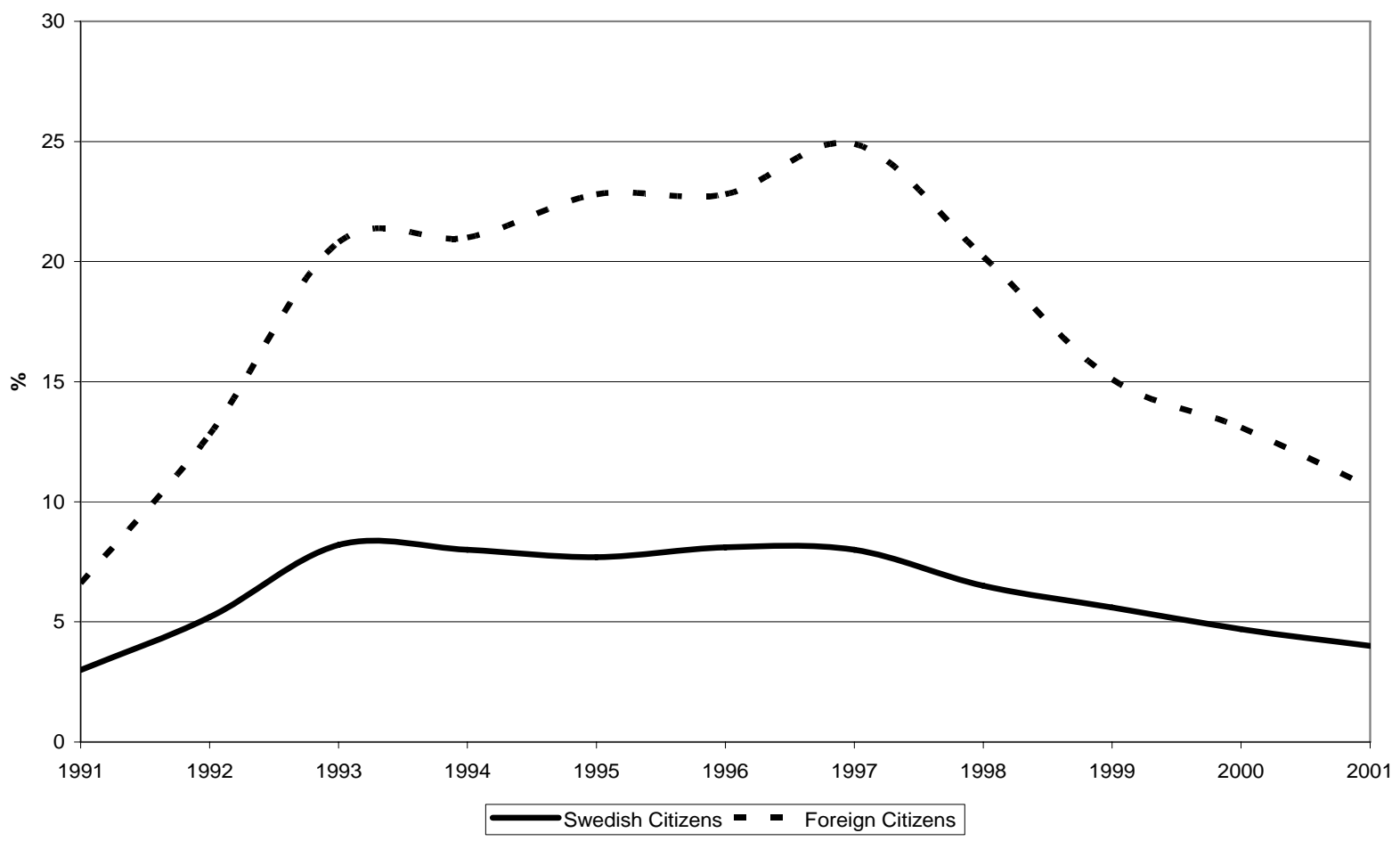

Figure 2. Immigration into Sweden, 1940-2001, Annual Inflow and Proportion of Population.

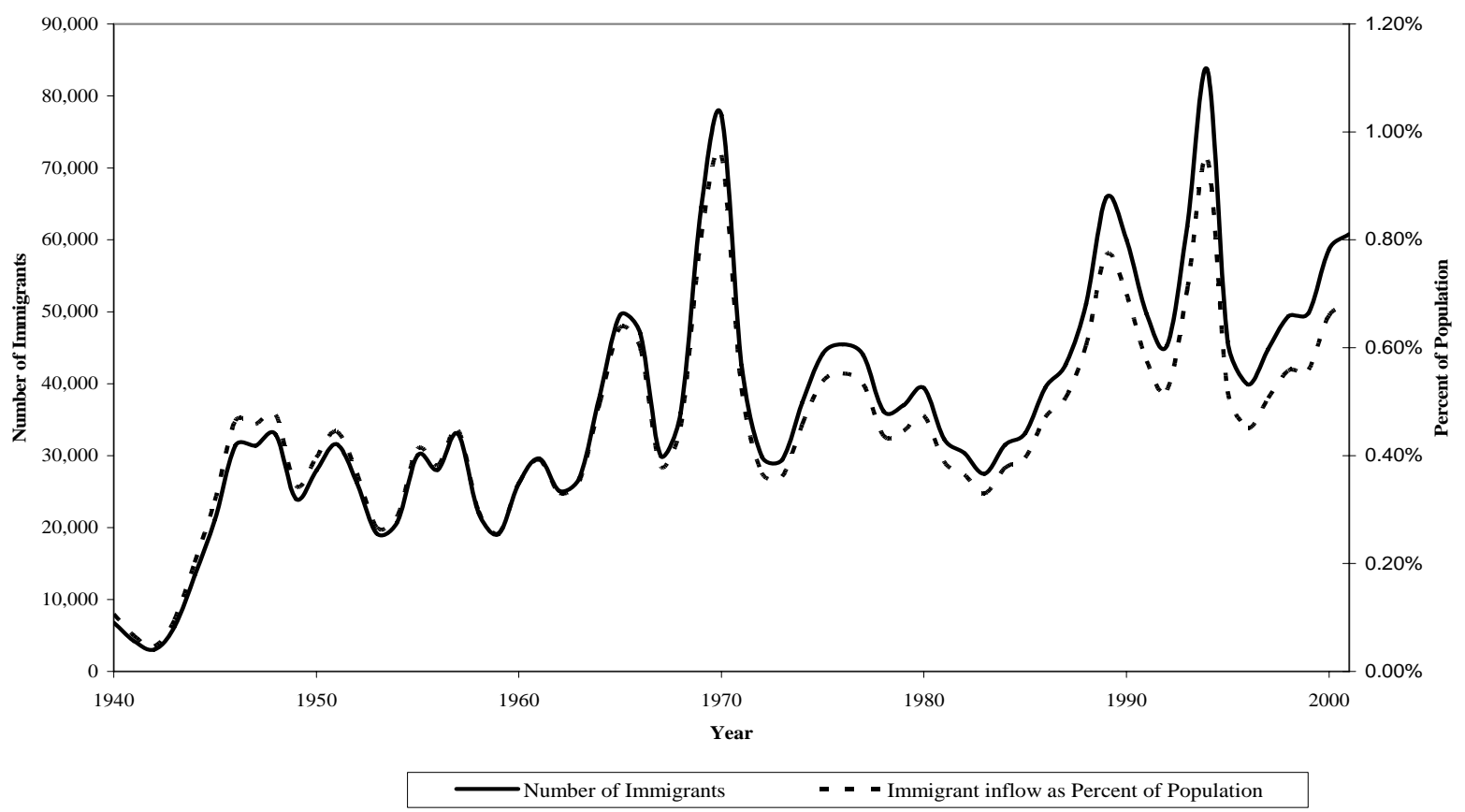




\section{$\underline{\text { Appendix }}$}

Table A1.

Observed Unconditional State Probabilities, 1991-2001, by Year, Gender and Immigrant Group, Balanced Panel.

\begin{tabular}{|c|c|c|c|c|c|c|}
\hline & \multirow[t]{2}{*}{ Natives } & \multicolumn{2}{|c|}{ Immigrants } & \multirow[t]{2}{*}{ Natives } & \multicolumn{2}{|c|}{ Immigrants } \\
\hline & & $\begin{array}{c}\text { Non- } \\
\text { Refugee }\end{array}$ & Refugee & & $\begin{array}{c}\text { Non- } \\
\text { Refugee }\end{array}$ & Refugee \\
\hline & \multicolumn{6}{|c|}{ Men } \\
\hline & \multicolumn{3}{|c|}{ Welfare } & \multicolumn{3}{|c|}{ Welfare and/or UI } \\
\hline $\begin{array}{l}\text { Period } \\
\text { Average }\end{array}$ & 3.14 & 8.17 & 20.21 & 12.14 & 18.97 & 37.82 \\
\hline 1991 & 3.57 & 10.00 & 28.63 & 7.32 & 15.71 & 36.42 \\
\hline 1992 & 3.92 & 10.10 & 24.76 & 11.58 & 20.39 & 38.66 \\
\hline 1993 & 4.21 & 9.95 & 26.44 & 15.91 & 24.24 & 45.83 \\
\hline 1994 & 3.84 & 9.80 & 24.24 & 16.24 & 24.48 & 45.41 \\
\hline 1995 & 3.42 & 9.36 & 21.78 & 14.24 & 22.33 & 43.06 \\
\hline 1996 & 3.24 & 8.48 & 20.49 & 13.16 & 20.95 & 40.31 \\
\hline 1997 & 3.15 & 7.98 & 19.37 & 13.25 & 19.12 & 39.53 \\
\hline 1998 & 2.60 & 6.70 & 16.85 & 11.97 & 17.74 & 36.67 \\
\hline 1999 & 2.40 & 7.00 & 16.07 & 11.02 & 17.50 & 34.66 \\
\hline 2000 & 2.28 & 5.52 & 13.61 & 10.07 & 13.95 & 30.57 \\
\hline \multirow[t]{3}{*}{2001} & 1.89 & 4.98 & 10.08 & 8.77 & 12.27 & 24.86 \\
\hline & \multicolumn{6}{|c|}{ Women } \\
\hline & \multicolumn{3}{|c|}{ Welfare } & \multicolumn{3}{|c|}{ Welfare and/or UI } \\
\hline $\begin{array}{l}\text { Period } \\
\text { Average }\end{array}$ & 2.74 & 4.93 & 9.37 & 12.00 & 15.76 & 28.04 \\
\hline 1991 & 3.46 & 6.79 & 12.62 & 7.00 & 11.29 & 19.46 \\
\hline 1992 & 3.32 & 6.24 & 10.83 & 9.40 & 13.44 & 23.31 \\
\hline 1993 & 3.59 & 6.09 & 11.26 & 13.46 & 18.13 & 32.86 \\
\hline 1994 & 3.30 & 5.99 & 10.34 & 14.01 & 19.58 & 33.02 \\
\hline 1995 & 3.08 & 5.34 & 9.99 & 13.90 & 18.97 & 33.02 \\
\hline 1996 & 3.01 & 5.64 & 9.91 & 14.03 & 18.67 & 33.81 \\
\hline 1997 & 2.82 & 4.79 & 9.91 & 14.35 & 18.37 & 33.81 \\
\hline 1998 & 2.28 & 4.44 & 8.42 & 13.30 & 15.93 & 30.03 \\
\hline 1999 & 2.01 & 3.65 & 7.92 & 11.99 & 15.08 & 27.10 \\
\hline 2000 & 1.71 & 2.90 & 6.63 & 11.04 & 13.23 & 23.47 \\
\hline 2001 & 1.57 & 2.30 & 5.28 & 9.52 & 10.63 & 18.55 \\
\hline
\end{tabular}




\section{Table A2.}

Distribution of Labor Market Spells, 1991-2001, by Immigrant Group and Gender, Balanced Panel.

\begin{tabular}{|c|c|c|c|c|c|c|}
\hline & \multicolumn{4}{|c|}{ Immigrants } & \multicolumn{2}{|c|}{ Immigrants } \\
\hline & \multicolumn{3}{|c|}{ Non- } & \multicolumn{2}{|c|}{ Non- } & Refugee \\
\hline $\begin{array}{l}\text { Percent with Number } \\
\text { of Spells Receiving: }\end{array}$ & \multicolumn{3}{|c|}{ Men } & \multicolumn{3}{|c|}{ Women } \\
\hline \multicolumn{7}{|l|}{ Welfare } \\
\hline 0 & 90.13 & 77.09 & 51.07 & 91.23 & 84.69 & 74.97 \\
\hline 1 & 3.20 & 6.55 & 9.86 & 2.96 & 4.34 & 6.13 \\
\hline 2 & 1.86 & 3.60 & 7.43 & 1.61 & 3.10 & 4.28 \\
\hline 3 & 1.19 & 2.41 & 5.82 & 1.08 & 2.15 & 3.14 \\
\hline 4 & 0.84 & 2.22 & 5.10 & 0.77 & 1.45 & 2.42 \\
\hline 5 & 0.61 & 1.63 & 3.98 & 0.54 & 1.10 & 1.78 \\
\hline 6 & 0.54 & 1.97 & 3.08 & 0.41 & 0.50 & 1.57 \\
\hline 7 & 0.38 & 1.08 & 3.58 & 0.33 & 0.73 & 1.28 \\
\hline 8 & 0.40 & 0.99 & 2.52 & 0.28 & 0.80 & 1.43 \\
\hline 9 & 0.31 & 0.84 & 2.41 & 0.25 & 0.50 & 0.71 \\
\hline 10 & 0.25 & 0.84 & 2.24 & 0.27 & 0.35 & 0.93 \\
\hline 11 (Entire Period) & 0.30 & 0.79 & 2.91 & 0.27 & 0.30 & 1.35 \\
\hline \multicolumn{7}{|l|}{ Welfare and/or UI } \\
\hline 0 & 68.75 & 57.36 & 31.42 & 68.73 & 60.92 & 41.15 \\
\hline 1 & 6.21 & 8.28 & 7.22 & 6.52 & 7.59 & 7.92 \\
\hline 2 & 5.69 & 5.72 & 6.94 & 5.26 & 6.04 & 7.42 \\
\hline 3 & 4.21 & 4.50 & 5.36 & 4.05 & 5.29 & 5.94 \\
\hline 4 & 3.20 & 3.70 & 7.11 & 3.22 & 3.40 & 5.28 \\
\hline 5 & 2.32 & 3.10 & 5.10 & 2.63 & 3.50 & 5.28 \\
\hline 6 & 2.00 & 3.45 & 4.65 & 2.22 & 2.90 & 5.71 \\
\hline 7 & 1.81 & 2.86 & 5.38 & 2.13 & 2.83 & 5.78 \\
\hline 8 & 1.75 & 2.81 & 5.77 & 1.66 & 2.55 & 4.49 \\
\hline 9 & 1.54 & 2.91 & 6.05 & 1.57 & 2.30 & 4.21 \\
\hline 10 & 1.30 & 2.81 & 6.38 & 1.13 & 1.30 & 3.57 \\
\hline 11 (Entire Period) & 1.21 & 2.51 & 8.62 & 0.89 & 1.40 & 3.28 \\
\hline Number of Individuals & 43,374 & 2,030 & 1,786 & 41,628 & 2,003 & 1,402 \\
\hline
\end{tabular}


Table A3.

Mean Characteristics by Previous Year's State, 1991-2001, Men by Immigrant Group, Balanced Panel.

\begin{tabular}{|c|c|c|c|c|}
\hline \multirow{2}{*}{$\begin{array}{r}\text { State at } \mathrm{t}-1: \\
\text { State at } \mathrm{t}:\end{array}$} & \multicolumn{2}{|c|}{ Welfare } & \multicolumn{2}{|c|}{ Not on Welfare } \\
\hline & No Change & Out of & No Change & Into \\
\hline & \multicolumn{4}{|c|}{ Natives } \\
\hline Age & 40.37 & 40.62 & 45.16 & 40.37 \\
\hline Elementary School & 0.403 & 0.348 & 0.265 & 0.350 \\
\hline High School & 0.533 & 0.558 & 0.484 & 0.560 \\
\hline College & 0.064 & 0.094 & 0.251 & 0.090 \\
\hline Large City Resident & 0.376 & 0.325 & 0.307 & 0.327 \\
\hline Medium City Resident & 0.426 & 0.438 & 0.445 & 0.437 \\
\hline Married & 0.199 & 0.308 & 0.685 & 0.319 \\
\hline Household Size & 1.75 & 2.06 & 2.68 & 2.11 \\
\hline Children & 0.224 & 0.320 & 0.424 & 0.332 \\
\hline Number of Children & 0.499 & 0.668 & 0.796 & 0.717 \\
\hline Number of Adults & 1.25 & 1.39 & 1.89 & 1.39 \\
\hline \multirow[t]{2}{*}{ Years Since Migrated } & $\mathrm{N} / \mathrm{A}$ & N/A & N/A & N/A \\
\hline & \multicolumn{4}{|c|}{ Non-Refugee Immigrants } \\
\hline Age & 42.18 & 41.57 & 44.94 & 41.19 \\
\hline Elementary School & 0.426 & 0.351 & 0.356 & 0.355 \\
\hline High School & 0.449 & 0.538 & 0.444 & 0.540 \\
\hline College & 0.126 & 0.111 & 0.200 & 0.105 \\
\hline Large City Resident & 0.559 & 0.516 & 0.506 & 0.525 \\
\hline Medium City Resident & 0.286 & 0.323 & 0.299 & 0.316 \\
\hline Married & 0.233 & 0.274 & 0.620 & 0.268 \\
\hline Household Size & 1.93 & 1.93 & 2.57 & 1.94 \\
\hline Children & 0.244 & 0.279 & 0.403 & 0.270 \\
\hline Number of Children & 0.598 & 0.571 & 0.756 & 0.598 \\
\hline Number of Adults & 1.33 & 1.35 & 1.82 & 1.34 \\
\hline \multirow[t]{2}{*}{ Years Since Migrated } & 17.38 & 18.13 & 20.36 & 17.94 \\
\hline & \multicolumn{4}{|c|}{ Refugee Immigrants } \\
\hline Age & 38.26 & 38.15 & 42.17 & 37.84 \\
\hline Elementary School & 0.462 & 0.337 & 0.261 & 0.352 \\
\hline High School & 0.370 & 0.467 & 0.477 & 0.486 \\
\hline College & 0.168 & 0.195 & 0.262 & 0.162 \\
\hline Large City Resident & 0.597 & 0.643 & 0.660 & 0.656 \\
\hline Medium City Resident & 0.342 & 0.299 & 0.256 & 0.298 \\
\hline Married & 0.546 & 0.485 & 0.661 & 0.505 \\
\hline Household Size & 2.91 & 2.56 & 2.95 & 2.58 \\
\hline Children & 0.503 & 0.441 & 0.522 & 0.443 \\
\hline Number of Children & 1.222 & 0.957 & 1.085 & 1.007 \\
\hline Number of Adults & 1.69 & 1.60 & 1.86 & 1.57 \\
\hline Years Since Migrated & 9.39 & 10.69 & 14.59 & 11.11 \\
\hline
\end{tabular}


Table A3 (Continued).

Mean Characteristics by Previous Year's State, 1991-2001, Men by Immigrant Group, Balanced Panel.

\begin{tabular}{|c|c|c|c|c|}
\hline \multirow{2}{*}{$\begin{array}{r}\text { State at t-1: } \\
\text { State at } \mathrm{t}:\end{array}$} & \multicolumn{2}{|c|}{ UI/Welfare } & \multicolumn{2}{|c|}{ Not on UI/Welfare } \\
\hline & No Change & Out of & No Change & Into \\
\hline & \multicolumn{4}{|c|}{ Natives } \\
\hline Age & 42.65 & 41.76 & 45.47 & 41.57 \\
\hline Elementary School & 0.326 & 0.281 & 0.262 & 0.298 \\
\hline High School & 0.563 & 0.566 & 0.472 & 0.553 \\
\hline College & 0.110 & 0.153 & 0.266 & 0.149 \\
\hline Large City Resident & 0.241 & 0.283 & 0.319 & 0.273 \\
\hline Medium City Resident & 0.493 & 0.453 & 0.438 & 0.472 \\
\hline Married & 0.455 & 0.537 & 0.700 & 0.546 \\
\hline Household Size & 2.17 & 2.45 & 2.72 & 2.42 \\
\hline Children & 0.319 & 0.405 & 0.431 & 0.389 \\
\hline Number of Children & 0.613 & 0.784 & 0.808 & 0.747 \\
\hline Number of Adults & 1.56 & 1.66 & 1.91 & 1.67 \\
\hline \multirow[t]{2}{*}{ Years Since Migrated } & N/A & N/A & $\mathrm{N} / \mathrm{A}$ & N/A \\
\hline & \multicolumn{4}{|c|}{ Non-Refugee Immigrants } \\
\hline Age & 42.07 & 42.84 & 45.36 & 41.64 \\
\hline Elementary School & 0.357 & 0.326 & 0.363 & 0.352 \\
\hline High School & 0.506 & 0.521 & 0.430 & 0.508 \\
\hline College & 0.137 & 0.153 & 0.207 & 0.141 \\
\hline Large City Resident & 0.414 & 0.494 & 0.530 & 0.487 \\
\hline Medium City Resident & 0.394 & 0.339 & 0.275 & 0.353 \\
\hline Married & 0.379 & 0.442 & 0.634 & 0.457 \\
\hline Household Size & 2.18 & 2.26 & 2.59 & 2.28 \\
\hline Children & 0.323 & 0.348 & 0.404 & 0.356 \\
\hline Number of Children & 0.692 & 0.691 & 0.753 & 0.696 \\
\hline Number of Adults & 1.49 & 1.57 & 1.84 & 1.59 \\
\hline \multirow[t]{2}{*}{ Years Since Migrated } & 17.95 & 19.05 & 20.69 & 17.72 \\
\hline & \multicolumn{4}{|c|}{ Refugee Immigrants } \\
\hline Age & 38.93 & 39.47 & 42.96 & 38.53 \\
\hline Elementary School & 0.361 & 0.302 & 0.263 & 0.311 \\
\hline High School & 0.453 & 0.469 & 0.461 & 0.489 \\
\hline College & 0.186 & 0.229 & 0.276 & 0.200 \\
\hline Large City Resident & 0.600 & 0.654 & 0.678 & 0.642 \\
\hline Medium City Resident & 0.335 & 0.280 & 0.234 & 0.290 \\
\hline Married & 0.543 & 0.572 & 0.686 & 0.585 \\
\hline Household Size & 2.75 & 2.80 & 3.02 & 2.82 \\
\hline Children & 0.474 & 0.501 & 0.534 & 0.511 \\
\hline Number of Children & 1.076 & 1.077 & 1.104 & 1.127 \\
\hline Number of Adults & 1.68 & 1.72 & 1.91 & 1.69 \\
\hline Years Since Migrated & 10.80 & 12.01 & 15.35 & 11.41 \\
\hline
\end{tabular}


Table A4.

Mean Characteristics by Previous Year's State, 1991-2001, Women by Immigrant Group, Balanced Panel.

\begin{tabular}{|c|c|c|c|c|}
\hline \multirow{2}{*}{$\begin{array}{r}\text { State at } \mathrm{t}-1: \\
\text { State at } \mathrm{t}:\end{array}$} & \multicolumn{2}{|c|}{ Welfare } & \multicolumn{2}{|c|}{ Not on Welfare } \\
\hline & No Change & Out of & No Change & Into \\
\hline & \multicolumn{4}{|c|}{ Natives } \\
\hline Age & 38.40 & 39.33 & 45.18 & 39.05 \\
\hline Elementary School & 0.401 & 0.303 & 0.213 & 0.296 \\
\hline High School & 0.506 & 0.553 & 0.508 & 0.572 \\
\hline College & 0.093 & 0.144 & 0.279 & 0.132 \\
\hline Large City Resident & 0.384 & 0.366 & 0.313 & 0.368 \\
\hline Medium City Resident & 0.416 & 0.431 & 0.446 & 0.430 \\
\hline Married & 0.077 & 0.153 & 0.709 & 0.142 \\
\hline Household Size & 2.15 & 2.16 & 2.76 & 2.18 \\
\hline Children & 0.543 & 0.506 & 0.440 & 0.520 \\
\hline Number of Children & 0.947 & 0.862 & 0.819 & 0.898 \\
\hline Number of Adults & 1.20 & 1.29 & 1.95 & 1.28 \\
\hline \multirow[t]{2}{*}{ Years Since Migrated } & N/A & N/A & N/A & N/A \\
\hline & \multicolumn{4}{|c|}{ Non-Refugee Immigrants } \\
\hline Age & 39.69 & 40.21 & 43.70 & 39.82 \\
\hline Elementary School & 0.518 & 0.397 & 0.299 & 0.377 \\
\hline High School & 0.404 & 0.483 & 0.456 & 0.487 \\
\hline College & 0.077 & 0.121 & 0.245 & 0.136 \\
\hline Large City Resident & 0.564 & 0.584 & 0.497 & 0.589 \\
\hline Medium City Resident & 0.327 & 0.296 & 0.318 & 0.304 \\
\hline Married & 0.076 & 0.150 & 0.655 & 0.161 \\
\hline Household Size & 2.16 & 2.32 & 2.81 & 2.36 \\
\hline Children & 0.567 & 0.581 & 0.491 & 0.582 \\
\hline Number of Children & 0.900 & 0.956 & 0.880 & 0.984 \\
\hline Number of Adults & 1.26 & 1.36 & 1.93 & 1.38 \\
\hline \multirow[t]{2}{*}{ Years Since Migrated } & 17.04 & 18.07 & 20.31 & 17.38 \\
\hline & \multicolumn{4}{|c|}{ Refugee Immigrants } \\
\hline Age & 40.16 & 39.38 & 41.88 & 39.30 \\
\hline Elementary School & 0.489 & 0.361 & 0.319 & 0.375 \\
\hline High School & 0.332 & 0.444 & 0.423 & 0.429 \\
\hline College & 0.179 & 0.195 & 0.257 & 0.196 \\
\hline Large City Resident & 0.684 & 0.679 & 0.602 & 0.639 \\
\hline Medium City Resident & 0.283 & 0.281 & 0.281 & 0.297 \\
\hline Married & 0.234 & 0.371 & 0.724 & 0.372 \\
\hline Household Size & 2.61 & 2.74 & 3.23 & 2.96 \\
\hline Children & 0.625 & 0.629 & 0.624 & 0.686 \\
\hline Number of Children & 1.156 & 1.123 & 1.209 & 1.341 \\
\hline Number of Adults & 1.45 & 1.62 & 2.02 & 1.61 \\
\hline Years Since Migrated & 11.38 & 12.14 & 14.54 & 11.93 \\
\hline
\end{tabular}


Table A4 (Continued).

Mean Characteristics by Previous Year's State, 1991-2001, Women by Immigrant Group, Balanced Panel.

\begin{tabular}{|c|c|c|c|c|}
\hline \multirow{2}{*}{$\begin{array}{r}\text { State at } \mathrm{t}-1: \\
\text { State at } \mathrm{t}:\end{array}$} & \multicolumn{2}{|c|}{ UI/Welfare } & \multicolumn{2}{|c|}{ Not on UI/Welfare } \\
\hline & No Change & Out of & No Change & Into \\
\hline & \multicolumn{4}{|c|}{ Natives } \\
\hline Age & 41.77 & 40.86 & 45.63 & 40.46 \\
\hline Elementary School & 0.281 & 0.214 & 0.211 & 0.235 \\
\hline High School & 0.579 & 0.577 & 0.496 & 0.580 \\
\hline College & 0.140 & 0.209 & 0.294 & 0.185 \\
\hline Large City Resident & 0.249 & 0.289 & 0.325 & 0.278 \\
\hline Medium City Resident & 0.473 & 0.448 & 0.442 & 0.462 \\
\hline Married & 0.496 & 0.555 & 0.716 & 0.581 \\
\hline Household Size & 2.54 & 2.72 & 2.76 & 2.74 \\
\hline Children & 0.477 & 0.523 & 0.433 & 0.520 \\
\hline Number of Children & 0.881 & 1.002 & 0.802 & 0.990 \\
\hline Number of Adults & 1.66 & 1.72 & 1.96 & 1.75 \\
\hline \multirow[t]{2}{*}{ Years Since Migrated } & N/A & N/A & N/A & $\mathrm{N} / \mathrm{A}$ \\
\hline & \multicolumn{4}{|c|}{ Non-Refugee Immigrants } \\
\hline Age & 40.29 & 40.83 & 44.29 & 39.39 \\
\hline Elementary School & 0.357 & 0.292 & 0.303 & 0.305 \\
\hline High School & 0.514 & 0.512 & 0.441 & 0.507 \\
\hline College & 0.130 & 0.195 & 0.256 & 0.188 \\
\hline Large City Resident & 0.409 & 0.482 & 0.518 & 0.475 \\
\hline Medium City Resident & 0.386 & 0.334 & 0.305 & 0.341 \\
\hline Married & 0.456 & 0.501 & 0.654 & 0.547 \\
\hline Household Size & 2.68 & 2.78 & 2.78 & 2.88 \\
\hline Children & 0.598 & 0.593 & 0.470 & 0.620 \\
\hline Number of Children & 1.054 & 1.052 & 0.835 & 1.133 \\
\hline Number of Adults & 1.63 & 1.73 & 1.94 & 1.75 \\
\hline \multirow[t]{2}{*}{ Years Since Migrated } & 18.44 & 18.92 & 20.58 & 17.49 \\
\hline & \multicolumn{4}{|c|}{ Refugee Immigrants } \\
\hline Age & 40.11 & 39.03 & 42.83 & 37.60 \\
\hline Elementary School & 0.355 & 0.321 & 0.325 & 0.354 \\
\hline High School & 0.442 & 0.442 & 0.406 & 0.428 \\
\hline College & 0.203 & 0.237 & 0.269 & 0.218 \\
\hline Large City Resident & 0.591 & 0.609 & 0.621 & 0.574 \\
\hline Medium City Resident & 0.304 & 0.302 & 0.266 & 0.330 \\
\hline Married & 0.550 & 0.678 & 0.710 & 0.716 \\
\hline Household Size & 3.06 & 3.31 & 3.16 & 3.47 \\
\hline Children & 0.681 & 0.707 & 0.586 & 0.746 \\
\hline Number of Children & 1.280 & 1.408 & 1.125 & 1.554 \\
\hline Number of Adults & 1.78 & 1.90 & 2.04 & 1.92 \\
\hline Years Since Migrated & 12.69 & 12.99 & 15.13 & 11.45 \\
\hline
\end{tabular}


Table A5: Parameter Estimates for Native Males.

\begin{tabular}{|c|c|c|c|c|c|c|c|c|}
\hline & \multicolumn{2}{|c|}{ Standard Logit } & \multicolumn{6}{|c|}{ Correlated Random } \\
\hline & Estimate & Std Err & Estimate & Std Err & Estimate & Std Err & Estimate & Std Err \\
\hline \multicolumn{9}{|l|}{ Individual Characteristics: } \\
\hline Age/100 & -1.607 & $(0.140)$ & -2.195 & $(0.181)$ & -1.561 & $(0.191)$ & n.a. & \\
\hline High School (Dummy) & -0.147 & $(0.028)$ & -0.147 & $(0.034)$ & -0.105 & $(0.033)$ & n.a. & \\
\hline College (Dummy) & -0.953 & $(0.042)$ & -0.988 & $(0.048)$ & -0.773 & $(0.051)$ & n.a. & \\
\hline Single (Dummy) & 1.783 & $(0.039)$ & 1.697 & $(0.041)$ & 0.712 & $(0.067)$ & 0.435 & $(0.241)$ \\
\hline Number of Children in Household & 0.386 & $(0.016)$ & 0.330 & $(0.017)$ & 0.113 & $(0.029)$ & 0.081 & $(0.115)$ \\
\hline Large City Resident (Dummy) & 0.172 & $(0.034)$ & 0.117 & $(0.039)$ & 0.026 & $(0.043)$ & n.a. & \\
\hline Medium City Resident (Dummy) & -0.018 & $(0.032)$ & -0.048 & $(0.036)$ & -0.055 & $(0.037)$ & n.a. & \\
\hline (Municipal Unemployment Rate)/10 & 0.670 & $(0.060)$ & 0.626 & $(0.067)$ & 0.356 & $(0.109)$ & n.a. & \\
\hline Years since migration & n.a. & & n.a. & & n.a. & & n.a. & \\
\hline \multicolumn{9}{|l|}{ State Dependence: } \\
\hline Received Welfare Previous Year & 4.615 & $(0.025)$ & 2.267 & $(0.030)$ & 2.102 & $(0.029)$ & 1.776 & $(0.080)$ \\
\hline \multicolumn{9}{|l|}{ Unobserved Heterogeneity: } \\
\hline Factor loading I & n.a. & & 0.959 & $(0.020)$ & n.a. & & n.a. & \\
\hline Factor loading II & n.a. & & 1.085 & $(0.031)$ & n.a. & & n.a. & \\
\hline Support point I & n.a. & & 2.302 & $(0.040)$ & 2.634 & $(0.038)$ & n.a. & \\
\hline Support point II & n.a. & & -0.434 & $(0.008)$ & -0.380 & $(0.006)$ & n.a. & \\
\hline Probability Type I & n.a. & & 0.159 & $(0.005)$ & 0.126 & $(0.003)$ & n.a. & \\
\hline Constant & -5.097 & $(0.096)$ & -4.624 & $(0.117)$ & -5.499 & $(0.132)$ & n.a. & \\
\hline Log-Likelihood & \multicolumn{2}{|c|}{$-32,017.0$} & \multicolumn{2}{|c|}{$-35,588.9$} & \multicolumn{2}{|c|}{$-29,303.2$} & & \\
\hline
\end{tabular}

Note: Quasi-maximum likelihood standard errors in parentheses, except for the Fixed Effects Logit, which has bootstrapped standard errors based on 100 replications. In all samples, individuals are observed in each of the $\mathrm{T}=11$ periods. To make parameter estimates comparable across models we use the standard Logit normalization (variance of composite error term equals $\pi^{2} / 3$ ). All specifications include time effects and these estimates are available upon request. Finally, the estimates in $\lambda_{m}$ are also available upon request. 
Table A6: Parameter Estimates for Native Females.

\begin{tabular}{|c|c|c|c|c|c|c|c|c|}
\hline & Standard Logit & Logit & \multicolumn{6}{|c|}{ Correlated Random } \\
\hline & Estimate & Std Err & Estimate & Std Err & Estimate & Std Err & Estimate & Std Err \\
\hline \multicolumn{9}{|l|}{ Individual Characteristics: } \\
\hline Age/100 & -2.974 & $(0.151)$ & -3.958 & $(0.208)$ & -3.280 & $(0.228)$ & n.a. & \\
\hline High School (Dummy) & -0.391 & $(0.032)$ & -0.417 & $(0.044)$ & -0.292 & $(0.040)$ & n.a. & \\
\hline College (Dummy) & -0.997 & $(0.041)$ & -1.193 & $(0.053)$ & -0.868 & $(0.050)$ & n.a. & \\
\hline Single (Dummy) & 2.831 & $(0.044)$ & 2.920 & $(0.050)$ & 1.780 & $(0.085)$ & 1.221 & $(0.267)$ \\
\hline Number of Children in Household & 0.435 & $(0.014)$ & 0.427 & $(0.018)$ & 0.024 & $(0.032)$ & 0.260 & $(0.156)$ \\
\hline Large City Resident (Dummy) & 0.135 & $(0.038)$ & 0.181 & $(0.047)$ & 0.082 & $(0.045)$ & n.a. & \\
\hline Medium City Resident (Dummy) & 0.019 & $(0.037)$ & 0.045 & $(0.044)$ & -0.015 & $(0.042)$ & n.a. & \\
\hline (Municipal Unemployment Rate)/10 & 0.349 & $(0.070)$ & 0.423 & $(0.077)$ & 0.134 & $(0.094)$ & n.a. & \\
\hline Years since migration & n.a. & & n.a. & & n.a. & & n.a. & \\
\hline \multicolumn{9}{|l|}{ State Dependence: } \\
\hline Received Welfare Previous Year & 4.009 & $(0.028)$ & 2.197 & $(0.034)$ & 1.916 & $(0.032)$ & 1.524 & $(0.086)$ \\
\hline \multicolumn{9}{|l|}{ Unobserved Heterogeneity: } \\
\hline Factor loading I & n.a. & & 0.881 & $(0.020)$ & n.a. & & n.a. & \\
\hline Factor loading II & n.a. & & 0.996 & $(0.033)$ & n.a. & & n.a. & \\
\hline Support point I & n.a. & & 2.196 & $(0.049)$ & 2.353 & $(0.040)$ & n.a. & \\
\hline Support point II & n.a. & & -0.456 & $(0.010)$ & -0.425 & $(0.007)$ & n.a. & \\
\hline Probability Type I & n.a. & & 0.172 & $(0.006)$ & 0.153 & $(0.004)$ & n.a. & \\
\hline Constant & -5.184 & $(0.107)$ & -4.713 & $(0.128)$ & -5.360 & $(0.155)$ & n.a. & \\
\hline Log-Likelihood & \multicolumn{2}{|c|}{$-25,689.7$} & \multicolumn{2}{|c|}{$-28,702.7$} & \multicolumn{2}{|c|}{$-23,584.6$} & & \\
\hline
\end{tabular}

Note: Quasi-maximum likelihood standard errors in parentheses, except for the Fixed Effects Logit, which has bootstrapped standard errors based on 100 replications. In all samples, individuals are observed in each of the $T=11$ periods. To make parameter estimates comparable across models we use the standard Logit normalization (variance of composite error term equals $\pi^{2} / 3$ ). All specifications include time effects and these estimates are available upon request. Finally, the estimates in $\lambda_{m}$ are also available upon request. 
Table A7: Parameter Estimates for Non-Refugee Males.

\begin{tabular}{|c|c|c|c|c|c|c|c|c|}
\hline & \multicolumn{2}{|c|}{ Standard Logit } & \multicolumn{6}{|c|}{ Correlated Random } \\
\hline & Estimate & Std Err & Estimate & Std Err & Estimate & Std Err & Estimate & Std Err \\
\hline \multicolumn{9}{|l|}{ Individual Characteristics: } \\
\hline Age/100 & -0.656 & $(0.458)$ & -1.245 & $(0.592)$ & -0.831 & $(0.636)$ & n.a. & \\
\hline High School (Dummy) & -0.014 & $(0.082)$ & 0.078 & $(0.101)$ & 0.001 & $(0.105)$ & n.a. & \\
\hline College (Dummy) & -0.342 & $(0.109)$ & -0.317 & $(0.140)$ & -0.289 & $(0.151)$ & n.a. & \\
\hline Single (Dummy) & 1.544 & $(0.113)$ & 1.520 & $(0.132)$ & 0.545 & $(0.199)$ & 0.181 & $(0.379)$ \\
\hline Number of Children in Household & 0.348 & $(0.047)$ & 0.301 & $(0.052)$ & 0.019 & $(0.082)$ & -0.160 & $(0.149)$ \\
\hline Large City Resident (Dummy) & 0.040 & $(0.103)$ & 0.022 & $(0.119)$ & -0.124 & $(0.146)$ & n.a. & \\
\hline Medium City Resident (Dummy) & -0.109 & $(0.113)$ & -0.159 & $(0.124)$ & -0.192 & $(0.141)$ & n.a. & \\
\hline (Municipal Unemployment Rate)/10 & 0.396 & $(0.175)$ & 0.404 & $(0.205)$ & 0.201 & $(0.363)$ & n.a. & \\
\hline Years since migration & -0.031 & $(0.032)$ & -0.039 & $(0.031)$ & -0.029 & $(0.032)$ & n.a. & \\
\hline Years since migration squared/100 & 0.041 & $(0.075)$ & 0.095 & $(0.072)$ & 0.027 & $(0.077)$ & n.a. & \\
\hline \multicolumn{9}{|l|}{ State Dependence: } \\
\hline Received Welfare Previous Year & 3.998 & $(0.073)$ & 2.148 & $(0.084)$ & 1.940 & $(0.081)$ & 2.353 & $(0.109)$ \\
\hline \multicolumn{9}{|l|}{ Unobserved Heterogeneity: } \\
\hline Factor loading I & n.a. & & 0.949 & $(0.050)$ & n.a. & & n.a. & \\
\hline Factor loading II & n.a. & & 1.196 & $(0.102)$ & n.a. & & n.a. & \\
\hline Support point I & n.a. & & 1.834 & $(0.095)$ & 2.148 & $(0.115)$ & n.a. & \\
\hline Support point II & n.a. & & -0.547 & $(0.028)$ & -0.467 & $(0.025)$ & n.a. & \\
\hline Probability Type I & n.a. & & 0.230 & $(0.018)$ & 0.179 & $(0.016)$ & n.a. & \\
\hline Constant & -3.954 & $(0.331)$ & -3.308 & $(0.373)$ & -4.726 & $(0.459)$ & n.a. & \\
\hline Log-Likelihood & \multicolumn{2}{|c|}{$-3,198.7$} & \multicolumn{2}{|c|}{$-3,585.1$} & \multicolumn{2}{|c|}{$-2,925.9$} & & \\
\hline
\end{tabular}


Table A8: Parameter Estimates for Non-Refugee Females.

\begin{tabular}{|c|c|c|c|c|c|c|c|c|}
\hline & \multicolumn{2}{|c|}{ Standard Logit } & \multicolumn{6}{|c|}{ Correlated Random } \\
\hline & Estimate & Std Err & Estimate & Std Err & Estimate & Std Err & Estimate & Std Err \\
\hline \multicolumn{9}{|l|}{ Individual Characteristics: } \\
\hline Age/100 & -2.055 & $(0.594)$ & -2.316 & $(0.738)$ & -4.197 & $(1.202)$ & n.a. & \\
\hline High School (Dummy) & -0.316 & $(0.101)$ & -0.419 & $(0.135)$ & -0.173 & $(0.128)$ & n.a. & \\
\hline College (Dummy) & -0.858 & $(0.135)$ & -1.078 & $(0.170)$ & -0.818 & $(0.167)$ & n.a. & \\
\hline Single (Dummy) & 2.148 & $(0.129)$ & 2.370 & $(0.150)$ & 1.105 & $(0.249)$ & -0.113 & $(0.299)$ \\
\hline Number of Children in Household & 0.249 & $(0.048)$ & 0.263 & $(0.061)$ & -0.155 & $(0.099)$ & 0.012 & $(0.163)$ \\
\hline Large City Resident (Dummy) & 0.331 & $(0.142)$ & 0.584 & $(0.162)$ & 0.393 & $(0.179)$ & n.a. & \\
\hline Medium City Resident (Dummy) & 0.288 & $(0.153)$ & 0.447 & $(0.166)$ & 0.321 & $(0.178)$ & n.a. & \\
\hline (Municipal Unemployment Rate)/10 & 0.279 & $(0.253)$ & 0.287 & $(0.283)$ & -0.115 & $(0.380)$ & n.a. & \\
\hline Years since migration & -0.048 & $(0.041)$ & -0.104 & $(0.042)$ & -0.056 & $(0.043)$ & n.a. & \\
\hline Years since migration squared/100 & 0.097 & $(0.094)$ & 0.220 & $(0.093)$ & 0.042 & $(0.099)$ & n.a. & \\
\hline \multicolumn{9}{|l|}{ State Dependence: } \\
\hline Received Welfare Previous Year & 3.678 & $(0.091)$ & 2.104 & $(0.103)$ & 1.801 & $(0.103)$ & 2.340 & $(0.093)$ \\
\hline \multicolumn{9}{|l|}{ Unobserved Heterogeneity: } \\
\hline Factor loading I & n.a. & & 0.910 & $(0.066)$ & n.a. & & n.a. & \\
\hline Factor loading II & n.a. & & 1.172 & $(0.144)$ & n.a. & & n.a. & \\
\hline Support point I & n.a. & & 1.831 & $(0.148)$ & 2.033 & $(0.143)$ & n.a. & \\
\hline Support point II & n.a. & & -0.550 & $(0.044)$ & -0.494 & $(0.035)$ & n.a. & \\
\hline Probability Type I & n.a. & & 0.232 & $(0.029)$ & 0.197 & $(0.022)$ & n.a. & \\
\hline Constant & -3.997 & $(0.423)$ & -3.552 & $(0.477)$ & -3.618 & $(0.673)$ & n.a. & \\
\hline Log-Likelihood & \multicolumn{2}{|c|}{$-2,076.4$} & \multicolumn{2}{|c|}{$-2,337.9$} & \multicolumn{2}{|c|}{$-1,903.7$} & & \\
\hline
\end{tabular}


Table A9: Parameter Estimates for Refugee Males.

\begin{tabular}{|c|c|c|c|c|c|c|c|c|}
\hline & \multicolumn{2}{|c|}{ Standard Logit } & \multicolumn{2}{|c|}{ Random Effects Logit } & $\begin{array}{r}\text { Correlate } \\
\text { Effect }\end{array}$ & $\begin{array}{l}\text { Random } \\
\text { ogit }\end{array}$ & \multicolumn{2}{|c|}{ Fixed Effects Logit } \\
\hline & Estimate & Std Err & Estimate & Std Err & Estimate & Std Err & Estimate & Std Err \\
\hline \multicolumn{9}{|l|}{ Individual Characteristics: } \\
\hline Age/100 & -0.368 & $(0.356)$ & -1.006 & $(0.473)$ & -0.213 & $(0.556)$ & n.a. & \\
\hline High School (Dummy) & -0.283 & $(0.063)$ & -0.291 & $(0.089)$ & -0.248 & $(0.088)$ & n.a. & \\
\hline College (Dummy) & -0.425 & $(0.074)$ & -0.478 & $(0.098)$ & -0.445 & $(0.102)$ & n.a. & \\
\hline Single (Dummy) & 0.441 & $(0.074)$ & 0.323 & $(0.085)$ & -0.346 & $(0.115)$ & -0.273 & $(0.309)$ \\
\hline Number of Children in Household & 0.150 & $(0.026)$ & 0.116 & $(0.034)$ & 0.098 & $(0.047)$ & -0.069 & $(0.139)$ \\
\hline Large City Resident (Dummy) & 0.263 & $(0.114)$ & 0.269 & $(0.130)$ & 0.251 & $(0.138)$ & n.a. & \\
\hline Medium City Resident (Dummy) & 0.318 & $(0.119)$ & 0.330 & $(0.134)$ & 0.299 & $(0.135)$ & n.a. & \\
\hline (Municipal Unemployment Rate)/10 & 0.764 & $(0.132)$ & 0.735 & $(0.158)$ & 0.441 & $(0.251)$ & n.a. & \\
\hline Years since migration & -0.136 & $(0.025)$ & -0.203 & $(0.028)$ & -0.147 & $(0.031)$ & n.a. & \\
\hline Years since migration squared/100 & 0.171 & $(0.076)$ & 0.340 & $(0.077)$ & 0.264 & $(0.080)$ & n.a. & \\
\hline \multicolumn{9}{|l|}{ State Dependence: } \\
\hline Received Welfare Previous Year & 3.548 & $(0.054)$ & 2.517 & $(0.067)$ & 2.215 & $(0.058)$ & 2.452 & $(0.090)$ \\
\hline \multicolumn{9}{|l|}{ Unobserved Heterogeneity: } \\
\hline Factor loading I & n.a. & & 0.804 & $(0.052)$ & n.a. & & n.a. & \\
\hline Factor loading II & n.a. & & 1.072 & $(0.100)$ & n.a. & & n.a. & \\
\hline Support point I & n.a. & & 1.420 & $(0.115)$ & 1.571 & $(0.095)$ & n.a. & \\
\hline Support point II & n.a. & & -0.709 & $(0.057)$ & -0.639 & $(0.039)$ & n.a. & \\
\hline Probability Type I & n.a. & & 0.334 & $(0.036)$ & 0.290 & $(0.025)$ & n.a. & \\
\hline Constant & -2.740 & $(0.241)$ & -1.618 & $(0.291)$ & -3.169 & $(0.357)$ & n.a. & \\
\hline Log-Likelihood & \multicolumn{2}{|c|}{$-4,976.9$} & \multicolumn{2}{|c|}{$-5,714.7$} & \multicolumn{2}{|c|}{$-4,754.6$} & & \\
\hline
\end{tabular}


Table A10: Parameter Estimates for Refugee Females.

\begin{tabular}{|c|c|c|c|c|c|c|c|c|}
\hline & \multicolumn{2}{|c|}{ Standard Logit } & \multicolumn{6}{|c|}{ Correlated Random } \\
\hline & Estimate & Std Err & Estimate & Std Err & Estimate & Std Err & Estimate & Std Err \\
\hline \multicolumn{9}{|l|}{ Individual Characteristics: } \\
\hline Age/100 & 0.340 & $(0.560)$ & -0.104 & $(0.700)$ & 0.990 & $(0.892)$ & n.a. & \\
\hline High School (Dummy) & -0.214 & $(0.103)$ & -0.272 & $(0.133)$ & -0.090 & $(0.136)$ & n.a. & \\
\hline College (Dummy) & -0.445 & $(0.120)$ & -0.586 & $(0.151)$ & -0.315 & $(0.148)$ & n.a. & \\
\hline Single (Dummy) & 1.496 & $(0.103)$ & 1.879 & $(0.129)$ & 1.428 & $(0.224)$ & 0.606 & $(0.442)$ \\
\hline Number of Children in Household & 0.231 & $(0.042)$ & 0.223 & $(0.049)$ & 0.104 & $(0.086)$ & -0.098 & $(0.157)$ \\
\hline Large City Resident (Dummy) & 0.334 & $(0.197)$ & 0.330 & $(0.222)$ & 0.343 & $(0.243)$ & n.a. & \\
\hline Medium City Resident (Dummy) & 0.402 & $(0.206)$ & 0.423 & $(0.228)$ & 0.461 & $(0.240)$ & n.a. & \\
\hline (Municipal Unemployment Rate)/10 & 0.150 & $(0.280)$ & 0.117 & $(0.308)$ & -0.112 & $(0.465)$ & n.a. & \\
\hline Years since migration & -0.048 & $(0.041)$ & -0.049 & $(0.044)$ & -0.019 & $(0.044)$ & n.a. & \\
\hline Years since migration squared/100 & -0.001 & $(0.115)$ & -0.043 & $(0.115)$ & -0.123 & $(0.120)$ & n.a. & \\
\hline \multicolumn{9}{|l|}{ State Dependence: } \\
\hline Received Welfare Previous Year & 4.192 & $(0.090)$ & 2.732 & $(0.103)$ & 2.623 & $(0.104)$ & 2.297 & $(0.111)$ \\
\hline \multicolumn{9}{|l|}{ Unobserved Heterogeneity: } \\
\hline Factor loading I & n.a. & & 0.925 & $(0.066)$ & n.a. & & n.a. & \\
\hline Factor loading II & n.a. & & 0.846 & $(0.105)$ & n.a. & & n.a. & \\
\hline Support point I & n.a. & & 1.648 & $(0.133)$ & 1.709 & $(0.174)$ & n.a. & \\
\hline Support point II & n.a. & & -0.611 & $(0.049)$ & -0.591 & $(0.060)$ & n.a. & \\
\hline Probability Type I & n.a. & & 0.272 & $(0.032)$ & 0.259 & $(0.039)$ & n.a. & \\
\hline Constant & -4.483 & $(0.405)$ & -3.923 & $(0.459)$ & -5.238 & $(0.596)$ & n.a. & \\
\hline Log-Likelihood & \multicolumn{2}{|c|}{$-2,073.2$} & \multicolumn{2}{|c|}{$-2,397.6$} & \multicolumn{2}{|c|}{$-1,973.7$} & & \\
\hline
\end{tabular}


Table A11.

Predicted and Observed Distributions of Welfare Participation for Males, Based on Estimates from the Correlated Random Effects Logit Model, by Nativity Group.

\begin{tabular}{|c|c|c|c|c|c|c|}
\hline & $\begin{array}{r}\text { Nat } \\
\text { Observed }\end{array}$ & $\begin{array}{l}\text { les } \\
\text { Predicted }\end{array}$ & $\begin{array}{r}\mathrm{Ma} \\
\text { Non-Re } \\
\text { Observed }\end{array}$ & $\begin{array}{l}\text { es } \\
\text { fugees } \\
\text { Predicted }\end{array}$ & $\begin{array}{r}\text { Refu } \\
\text { Observed }\end{array}$ & $\begin{array}{l}\text { yees } \\
\text { Predicted }\end{array}$ \\
\hline \multicolumn{7}{|l|}{ Year: } \\
\hline 1992 & 0.039 & 0.035 & 0.101 & 0.096 & 0.247 & 0.248 \\
\hline 1993 & 0.042 & 0.034 & 0.100 & 0.090 & 0.264 & 0.260 \\
\hline 1994 & 0.038 & 0.029 & 0.098 & 0.086 & 0.243 & 0.234 \\
\hline 1995 & 0.034 & 0.025 & 0.094 & 0.081 & 0.217 & 0.207 \\
\hline 1996 & 0.032 & 0.024 & 0.085 & 0.072 & 0.205 & 0.194 \\
\hline 1997 & 0.032 & 0.023 & 0.080 & 0.066 & 0.193 & 0.181 \\
\hline 1998 & 0.026 & 0.018 & 0.067 & 0.055 & 0.168 & 0.153 \\
\hline 1999 & 0.024 & 0.017 & 0.070 & 0.058 & 0.160 & 0.147 \\
\hline 2000 & 0.023 & 0.016 & 0.055 & 0.044 & 0.136 & 0.120 \\
\hline 2001 & 0.019 & 0.013 & 0.050 & 0.040 & 0.100 & 0.083 \\
\hline
\end{tabular}


Table A12.

Predicted and Observed Distributions of Welfare Participation for Females, Based on Estimates from the Correlated Random Effects Logit Model, by Nativity Group.

\begin{tabular}{|c|c|c|c|c|c|c|}
\hline & $\begin{array}{r}\text { Nat } \\
\text { Observed } \\
\end{array}$ & $\begin{array}{l}\text { ves } \\
\text { Predicted }\end{array}$ & $\begin{array}{r}\text { Fem } \\
\text { Non-Re } \\
\text { Observed } \\
\end{array}$ & $\begin{array}{l}\text { ales } \\
\text { fugees } \\
\text { Predicted } \\
\end{array}$ & $\begin{array}{r}\text { Refu } \\
\text { Observed } \\
\end{array}$ & $\begin{array}{l}\text { gees } \\
\text { Predicted } \\
\end{array}$ \\
\hline \multicolumn{7}{|l|}{ Year: } \\
\hline 1992 & 0.033 & 0.030 & 0.063 & 0.060 & 0.108 & 0.105 \\
\hline 1993 & 0.036 & 0.031 & 0.061 & 0.055 & 0.113 & 0.104 \\
\hline 1994 & 0.033 & 0.027 & 0.060 & 0.052 & 0.103 & 0.092 \\
\hline 1995 & 0.031 & 0.024 & 0.053 & 0.045 & 0.100 & 0.088 \\
\hline 1996 & 0.030 & 0.024 & 0.057 & 0.050 & 0.099 & 0.087 \\
\hline 1997 & 0.028 & 0.022 & 0.049 & 0.042 & 0.099 & 0.086 \\
\hline 1998 & 0.023 & 0.017 & 0.045 & 0.039 & 0.084 & 0.068 \\
\hline 1999 & 0.020 & 0.015 & 0.036 & 0.030 & 0.079 & 0.066 \\
\hline 2000 & 0.017 & 0.013 & 0.029 & 0.024 & 0.066 & 0.053 \\
\hline 2001 & 0.016 & 0.012 & 0.023 & 0.019 & 0.053 & 0.040 \\
\hline
\end{tabular}

